\title{
A combination of PD-1/PD-L1 inhibitors: The prospect of overcoming the weakness of tumor immunotherapy (Review)
}

\author{
XIANBIN KONG ${ }^{1 *}$, PENG LU $^{2 *}$, CHUANXIN LIU $^{3 *}$, YUZHU GUO $^{4}$, YUYING YANG $^{1}$, YINGYING PENG $^{1}$, \\ FANGYUAN WANG $^{1}$, ZHICHAO BO ${ }^{1}$, XIAOXIN DOU ${ }^{1}$, HAOYANG SHI $^{1}$ and JINGYAN MENG $^{1}$
}

${ }^{1}$ Integrated Traditional Chinese and Western Medicine Laboratory, College of Traditional Chinese Medicine, Tianjin University of Traditional Chinese Medicine, Tianjin 301617; ${ }^{2}$ State Key Laboratory of Component-Based Chinese Medicine,

Tianjin University of Traditional Chinese Medicine, Tianjin 301617; ${ }^{3}$ Department of Pharmaceutical Analysis,

School of Chinese Materia Medical, Beijing University of Chinese Medicine, Beijing 102488;

${ }^{4}$ Department of Radiotherapy, Tianjin Hospital, Tianjin 300211, P.R. China

Received August 15, 2020; Accepted February 8, 2021

DOI: $10.3892 / \mathrm{mmr} .2021 .12001$

\begin{abstract}
Programmedcelldeathprotein-1(PD-1)/programmed death protein ligand-1 (PD-L1) inhibitors for treatment of a various types of cancers have revolutionized cancer immunotherapy. However, PD-1/PD-L1 inhibitors are associated with a low response rate and are only effective on a small number of patients with cancer. Development of an anti-PD-1/PD-L1 sensitizer for improving response rate and effectiveness of immunotherapy is a challenge. The present study reviews the synergistic effects of PD-1/PD-L1 inhibitor with oncolytic virus, tumor vaccine, molecular targeted drugs, immunotherapy, chemotherapy, radiotherapy, intestinal flora
\end{abstract}

Correspondence to: Professor Jingyan Meng, Integrated Traditional Chinese and Western Medicine Laboratory, College of Traditional Chinese Medicine, Tianjin University of Traditional Chinese Medicine, 10 Poyanghu Road, West Area, Jinghai, Tianjin 301617, P.R. China

E-mail: mengjy@163.com

${ }^{*}$ Contributed equally

Abbreviations: CTLA-4, cytotoxic T-lymphocyte antigen-4; CTLs, cytotoxic T lymphocytes; DC, dendritic cell; IDO, indoleamine 2, 3-dioxygenase; IFN- $\gamma$, interferon- $\gamma$; LAG3, lymphocyte activation gene-3; ICIs, immune checkpoint inhibitors; IR, irradiation; MDSCs, myeloid-derived suppressor cells; MSI, microsatellite instability; NSCLC, non-small cell lung cancer; OVs, oncolytic virus; ORR, objective response rate; $\mathrm{PR}$, partially responsive; $\mathrm{PD}-1$, programmed cell death protein-1; PD-L1, programmed death protein ligand-1; PFS, progression-free survival; RT, radiotherapy; SD, stable disease; SBRT, stereotactic body radiotherapy; TIL, tumor infiltrating lymphocyte; TIGIT, T cell immunoreceptor with Ig and ITIM domains; TMB, tumor mutation burden; US FDA, United States Food and Drug Administration; VEGF, vascular endothelial growth factor

Key words: oncolytic virus, cancer vaccine, molecular targeted therapy, immunotherapy, intestinal flora, Traditional Chinese Medicine and traditional Chinese medicine, to provide information for development of effective combination therapies.

\section{Contents}

1. Introduction

2. Combination of oncolytic virus (OVs) with PD-1/PD-L1 inhibitors

3. Combination of cancer vaccine with PD-1/PD-L1 inhibitors

4. Combination of molecular targeting drugs with PD-1/PD-L1 inhibitors

5. Combination of chemotherapy with PD-1/PD-L1 inhibitors

6. Combination of radiotherapy with PD-1/PD-L1 inhibitors

7. Combination of intestinal microflora with PD-1/PD-L1 inhibitors

8. Combination of Traditional Chinese Medicine with PD-1/PD-L1 inhibitors

9. Conclusion and future perspectives

\section{Introduction}

Advances in immunotherapy have revolutionized cancer therapy. Programmed death receptor-1 [programmed cell death protein 1 (PD-1)] and programmed death protein ligand-1 [programmed death-ligand 1 (PD-L1)] inhibitors, have improved tumor therapy in cancer immunotherapy (1). The combination of PD-1 and PD-L1 inhibits the activity of $\mathrm{T}$ cells and act as the 'brake' of immunity, thereby preventing effector immune cells from killing cancer cells (2). Common PD-1/PD-L1 inhibitors in clinical used include Nivolumab, Pembrolizumab, Atezolizumab, Durvalumab and Avelumab (3). PD-1/PD-LI inhibitors block PD-1/PD-L1 pathway to restore normal immune function of $\mathrm{T}$ cells. Effector $\mathrm{T}$ cells play a role in recognizing and killing tumors (4). Various PD-1/PD-L1 inhibitors have been approved by the United States Food and Drug Administration (US FDA) for the treatment of various tumors (5). PD-1/PD-L1 inhibitors are characterized by high efficacy and fewer adverse events (6). However, PD-1/PD-LI 
inhibitors are associated with low response rate when used as a monotherapy with few patients meeting the treatment conditions and the high cost of treatment (7). In addition, immune regulatory signaling pathways are complex, so even those patients who are initially sensitive to PD-1/PD-L1 therapy may develop resistance or relapse. Therefore, there is need to develop approaches to improve sensitivity of PD-1/PD-LI inhibitors (8).

Tumor-related gene deletions and mutations are implicated in anti-PD-1/PD-LI resistance (9). For example, Janus kinase (JAK)1, JAK2 and $\beta 2$ microglobulin mutations cause antigen presentation barriers, which induce CD8-infiltrated $\mathrm{T}$ cells to lose major histocompatibility complex (MHC) I and reduce sensitivity to IFN- $\gamma$ (10). Mutation or activation of epidermal growth factor receptor (EGFR), T cell immunoglobulin mucin 3 (Tim-3), lymphocyte activation gene-3 (LAG-3), T cell Ig and ITIM domain (TIGIT) and other $\mathrm{T}$ cell depletion-related protein receptors results in a gradual loss of $\mathrm{T}$ cell proliferative potential and effector function, thus inducing drug resistance against PD-1 inhibitors (11-13). Immune checkpoint inhibitors (ICIs) inhibit checkpoints of the immune system rather than directly enhancing immune function. A single ICI is not effective in activating immune response. Therefore, there is a requirement to explore novel alternative strategies and personalized immunotherapy strategies through a combination of PD-1/PD-L1 inhibitors with small molecular targets, chemotherapy and radiotherapy to improve sensitivity to activated anti-tumor immune response and the response rate of patients and solve the bottleneck of drug resistance (14). The present study summarizes previous studies on the anti-tumor effects of PD-1/PD-LI inhibitors combination therapy to provide information for clinical and basic research (Fig. 1).

\section{Combination of oncolytic virus (OVs) with PD-1/PD-L1 inhibitors}

Tumor virus therapy induces immunogenic death on target cells and induces immune response by releasing pathogen-associated molecular pattern and damage-associated molecular pattern $(15,16)$. As a result, tumor virus therapy improves the sensitivity of tumor cells to immunotherapy thus improving therapeutic effect. OVs mediates clearance of cancer cells or killing of cancer cells by targeting the tumor vascular system and inducing immunity (17). Talimogene laherparepvec, a herpes simplex virus expressing granulocyte-macrophage colony stimulating factor, was the first US FDA approved oncolytic therapy (18). Local intratumoral injection of the virus into tumors improves the overall survival rate of patients (19). A previous study (7) reported on the treatment of 21 patients with advanced melanoma with Talimogene laherparepvec combined with Pembrolizumab. The study report that therapy was well tolerated, with fatigue, fevers and chills as the common adverse events. The therapy showed no dose-dependent toxic reaction and an objective response rate (ORR) of $62 \%$. Patients who responded to the combination therapy showed an increase number of CD8+T cells (7). Vaccinia virus is a highly immunogenic oncolytic immunotherapy vector $(20,21)$. Previous studies report that vaccinia virus attracts effector $\mathrm{T}$ cells in mouse model of colorectal cancer and ovarian cancer $(22,23)$. A combination of vaccinia virus with PD-L1 inhibitor enhances the infiltration of effector CD4+ and CD8+T cells and increases granzyme B, ICOS, perforin and IFN- $\gamma$, thus improving the survival rate (23).

PD-1/PD-L1 drug resistance is a main challenge, therefore, studies are required to explore novel approaches to improve immunogenicity of tumors and overcome resistance to immunotherapy (8). Rotavirus vaccine has immunostimulatory and anti-tumor effects (24). Administration of rotavirus in tumors overcomes drug resistance against PD-L1 inhibitors and has a synergistic effect with PD-L1 inhibitors. Heat- and UV-inactivated rotaviruses have no oncolytic activity but offer a synergistic effect with immune checkpoint-targeted antibodies through upregulation of the double-stranded RNA receptor retinoic acid-induced gene 1 (25). Rotaviruses have been used clinically and can be used for clinical sensitization of anti-PD-1/PD-L1 therapy (25) (Table I).

\section{Combination of cancer vaccine with PD-1/PD-L1 inhibitors}

Tumor vaccine enhances immunogenicity and activates the immune system of the patient, thus controlling or eliminating tumors (26). DNA vaccine, a universal and personalized cancer treatment containing multiple new antigen coding sequences, is ideal for new antigen vaccination (27). DNA vaccine induces Cytotoxicity of CD8 T cells. A single dose of DNA vaccine combined with anti-PD-1 treatment significantly delays tumor growth in tumor-bearing mice inoculated with MC38 colon cancer cell line and some of the tumors are cleared completely, with a cure rate of $25 \%$, and this indicates that tumor vaccine works synergistically with immune checkpoint blocking therapy (28).

Lmdd-MPFG vaccine promotes expression of PD-L1 in $\mathrm{HCC}$ cells but re-sensitizes tumor local $\mathrm{T}$ cell to respond to anti-PD-1 immunotherapy (29). Lmdd-MPFG vaccine activates $\mathrm{NF}-\kappa \mathrm{B}$ pathway and autophagy pathway in tumor-associated macrophages (TAMS). In addition, it converts M2 TAMS to M1 and induces the expression of antineoplastic factors, thus restoring T cell response to PD-1 inhibitors (29). Lmdd-MPFG vaccine acts synergistically with PD-1 inhibitors in treatment of liver cancer (29).

The tumor vaccine OVA @ Mn-DAP with nano-scale coordination polymer as a carrier, prepared from $\mathrm{Mn}^{2+}$ ions, Nod1 agonist and DAP as organic ligands, promotes maturation of dendritic cells and cross-presentation of antigens. Further, it prevents occurrence of B16-OVA tumors and works synergistically with PD-1 inhibitors to inhibit tumor growth (30).

Nivolumab combined with a multi-peptide vaccine (gp100, MART-1 and NY-ESO-1 with Montanide ISA 51 VG) was investigated as adjuvant therapy in resected stage IIIC and IV melanoma patients (31). The study findings showed that the treatment strategy was well tolerated. Common adverse events observed included fatigue, rash/pruritus, nausea/diarrhea, arthralgias and endocrinopathies. Although related grade 3 events occurred in 4 out of 33 patients, they were manageable. Notably, the combination therapy significantly increases CD8+ T-cell levels and decreases PD-1 expressing T-cells. In 


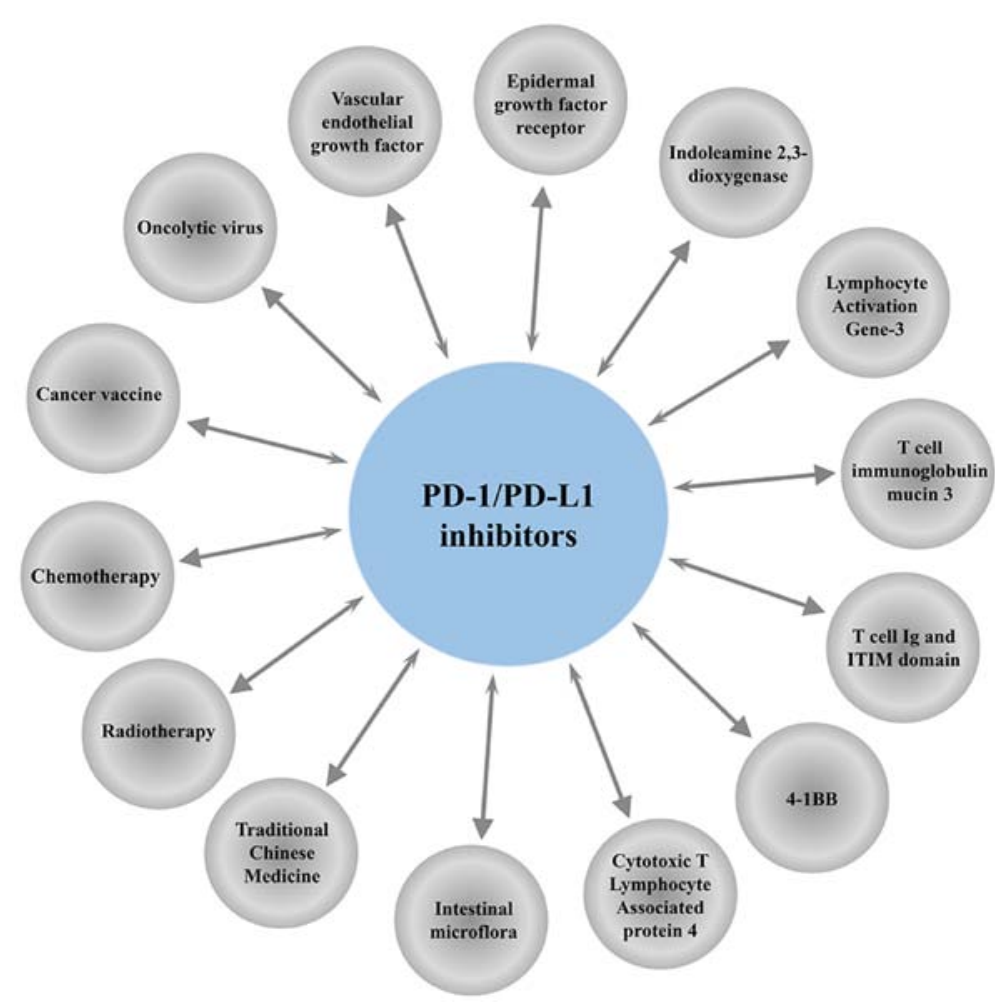

Figure 1. Schematic diagram of combined treatment regimen for PD-1/PD-L1 inhibitors. PD-1, programmed cell death protein-1; PD-L1, programmed death protein ligand-1.

addition, significant increases in $\mathrm{CD} 25+$ regulatory $\mathrm{T}$ cells (Tregs)/CTLA4+/CD4+ T-cell populations are observed with anti-PD-1 therapy (31). These findings imply that synergistic activity of nivolumab and anti-PD-1 therapy is mediated through CTLA-4 and/or Tregs (32).

A previous phase I study (33) evaluated a vaccine that targets $\leq 20$ predicted personal tumor neoantigens in patients with previously untreated high-risk melanoma following surgical resection. In that study, vaccine-induced polyfunctional CD4+ and CD8+ T cells targeted 58 (60\%) and $15(16 \%)$ of the 97 unique neoantigens used across patients, respectively. These $\mathrm{T}$ cells discriminated mutated antigens from wild-type antigens and recognized autologous tumors. Out of the six vaccinated patients, four showed no recurrence at 25 months following vaccination, whereas two showed recurrent disease and were subsequently treated with anti-PD-1 (pembrolizumab) therapy achieving complete tumor regression, with the expansion of a repertoire of neoantigen-specific T cells (33).

A previous study (34) explored the synergistic effect of a vaccine targeting HER $2 \Delta 16$ on anti-PD-1 therapy in enhancing antitumor immunity in a model of advanced HER2 ${ }^{+}$ breast cancer. HER $2 \Delta 16$ is a critical oncogenic pathway and spontaneous tumors driven by HER $2 \Delta 16$ are reflective of clinically advanced immunosuppressive HER $2^{+}$breast cancer. Endogenous HER $2 \Delta 16^{+}$breast cancers show no response to anti-PD-1 as a single agent. Treatment with anti-PD-1 is not effective in increasing systemic anti-HER2 T-cell responses. However, combination of anti-PD-1 with Ad-HER2 $\Delta 16-\mathrm{KI}$ significantly increases survival rate, with $\sim 30 \%$ of mice exhibiting complete tumor regression and long-term tumor-free survival. These findings show that vaccinated mice are characterized by a high IFN- $\gamma$ gene signature score. In addition, the results show that HER $2 \Delta 16$ vaccination induces systemic adaptive immune responses and increases HER2-specific CD8 T cells that infiltrate into tumors. Therefore, addition of anti-PD-1 effectively induces HER2-specific $\mathrm{T}$ cells in TME (34) (Table II).

\section{Combination of molecular targeting drugs with PD-1/PD-L1 inhibitors}

Combined application of vascular endothelial growth factor (VEGF) and PD-1/PD-L1 inhibitors. VEGF is an angiogenic factor that regulates the growth and survival of vascular endothelial cells, thereby causing immunosuppression (35) (Fig. 2). VEGF inhibitors are used to prevent angiogenesis and to promote differentiation of immune cells. Co-blocking of PD-1 and VEGF enhances efficacy of PD-1 inhibition (36). A clinical trial showed that the combination of VEGF and PD-1 inhibitors is effective in cancer treatment (NCT01472081) (37). Another study reported that PD-L1 inhibitors combined with VEGF receptor 2 (R2) small molecule inhibitors significantly downregulated the expression levels of PD-1 and PD-L1, and inhibited tumor growth by increasing tumor infiltrating lymphocytes (TILs) and decreasing Tregs and myeloid-derived suppressor cells (MDSCs) (38).

Bevacizumab was the first antiangiogenic drug and vascular modulator used for clinical treatment of solid tumors (39). Bevacizumab binds to vascular endothelial growth factor A, blocks interaction of its receptor VEGFR-1/VEGFR-2, induces tumor vascular degradation and inhibits tumor growth. Bevacizumab confers immunomodulatory effects by inhibiting VEGF and promoting DC maturation (40). In addition, it reverses immunosuppression by increasing $\mathrm{T}$ cell 
Table I. Combination therapy of oncolytic viruses with PD-1/PD-L1 inhibitors.

\begin{tabular}{|c|c|c|c|c|}
\hline Author(s) (year) & Interventions & Primary end point(s) & Results & (Refs.) \\
\hline Ribas et al, 2017 & Talimogene laherparepvec + Pembrolizumab & $\begin{array}{l}\text { ORR } \\
\text { CD8+ T cells }\end{array}$ & $\begin{array}{c}62 \% \\
\text { Increased }\end{array}$ & (7) \\
\hline Liu et al, 2017 & Vaccinia virus + Anti-PD-L1 & $\begin{array}{l}\text { Tumor burden } \\
\text { Survival rate } \\
\text { Granzyme B, Perforin, IFN- } \gamma \text {, } \\
\text { ICOS, Effector CD4+ and } \\
\text { CD } 8+T \text { cells }\end{array}$ & $\begin{array}{l}\text { Reduced } \\
\text { Improved } \\
\text { Increased }\end{array}$ & (23) \\
\hline Shekarian et al, 2019 & Rotavirus vaccine + Anti-PD-L1 & $\begin{array}{l}\text { Tumor size } \\
\text { Percent survival }\end{array}$ & $\begin{array}{l}\text { Reduced } \\
\text { Improved }\end{array}$ & $(25)$ \\
\hline
\end{tabular}

PD-1, programmed cell death protein-1; PD-L1, programmed death protein ligand-1.

Table II. Combination of cancer vaccines with PD-1/PD-L1 inhibitors.

\begin{tabular}{|c|c|c|c|c|}
\hline Author(s) (year) & Interventions & Primary end point(s) & Results & (Refs.) \\
\hline Tondini et al, 2019 & DNA vaccine + Anti-PD-1 & $\begin{array}{l}\text { Tumor growth } \\
\text { Cure rate }\end{array}$ & $\begin{array}{l}\text { Delayed } \\
25 \%\end{array}$ & $(28)$ \\
\hline $\mathrm{Xu}$ et al, 2020 & Anti-PD-1 + Lmdd-MPFG vaccine & $\begin{array}{l}\text { Percent survival } \\
\text { Tumor volume } \\
\text { TAMS } \\
\text { PD-L1 }\end{array}$ & $\begin{array}{l}\text { Prolonged } \\
\text { Retardation } \\
\text { Converted M2 TAMS to M1 } \\
\text { Promoted }\end{array}$ & $(29)$ \\
\hline Zhao et al, 2019 & OVA@Mn-DAP vaccine + Anti-PD-1 & $\begin{array}{l}\text { Tumor-infiltrating } \\
\text { lymphocytes } \\
\text { Tumor size } \\
\text { Percent survival }\end{array}$ & $\begin{array}{l}\text { Increased } \\
\text { Inhibited } \\
\text { Prolonged }\end{array}$ & $(30)$ \\
\hline Gibney et al, 2015 & Nivolumab + A multi-peptide vaccine & $\begin{array}{l}\text { CD8+/CD25+Treg/ } \\
\text { CTLA4+/CD4+ T-cells } \\
\text { PD-1 }\end{array}$ & $\begin{array}{l}\text { Increased } \\
\text { Decreased }\end{array}$ & $(31)$ \\
\hline Crosby et al, 2020 & $\begin{array}{l}\text { Ad-HER2D16-KI + Anti-PD-1 vs. } \\
\text { Anti-PD-1 }\end{array}$ & $\begin{array}{l}\text { Survival } \\
\text { IFN- } \gamma\end{array}$ & $\begin{array}{l}\text { Prolonged } \\
\text { Increased }\end{array}$ & $(34)$ \\
\hline
\end{tabular}

PD-1, programmed cell death protein-1; PD-L1, programmed death protein ligand-1.

infiltration. Furthermore, it enhances anti-tumor activity of PD-L1 antibody Atezolizumab (41). Phase III randomized controlled trials showed that Atezolizumab combined with chemotherapy and Bevacizumab improves progression-free survival (PFS) and overall survival (OS) of patients with metastatic NSCLC. Moreover, Bevacizumab monoclonal antibody increases sensitivity of Atezolizumab therapy (42) (Table III).

Combined application of EGFR and PD-1/PD-L1 inhibitors. EGFR is a transmembrane tyrosine kinase receptor, implicated in tumor cell proliferation, invasion and metastatic angiogenesis (43) (Fig. 2). EGFR tyrosine kinase inhibitor (EGFR-TKI) inhibits EGFR, reduces T cell apoptosis and increases production of IFN- $\gamma(44)$. However, most patients develop acquired drug resistance following EGFR-TKIs treatment (45). Activation of
EGFR pathway during tumorigenesis induces tumor immune escape mediated by PD-L1 (46). A previous study has explored the combination of PD-1/PD-L1 inhibitors and EGFR-TKIs for clinical use. Efficacy of PD-1/PD-L1 inhibitors combined with EGFR-TKIs in treatment of advanced EGFR mutant NSCLC has not yet been fully explored. Advanced patients with NSCLC and acquired tolerance to first or second generation of EGFR-TKIs should be treated with third generation of EGFR-TKIs before PD-1/PD-L1 inhibitors in case of a T790M mutation (47). In EGFR-TKIs-resistant EGFR mutant NSCLC, positive expression rate of PD-L1 in T790M negative patients was higher compared with that in T790M-positive patients (48). T790M negative patients were more sensitive to anti-PD-1 therapy after EGFR-TKIs treatment (48). Another clinical study reports that patients with advanced NSCLC and EGFR mutations show immune responses to PD-1/PD-L1 


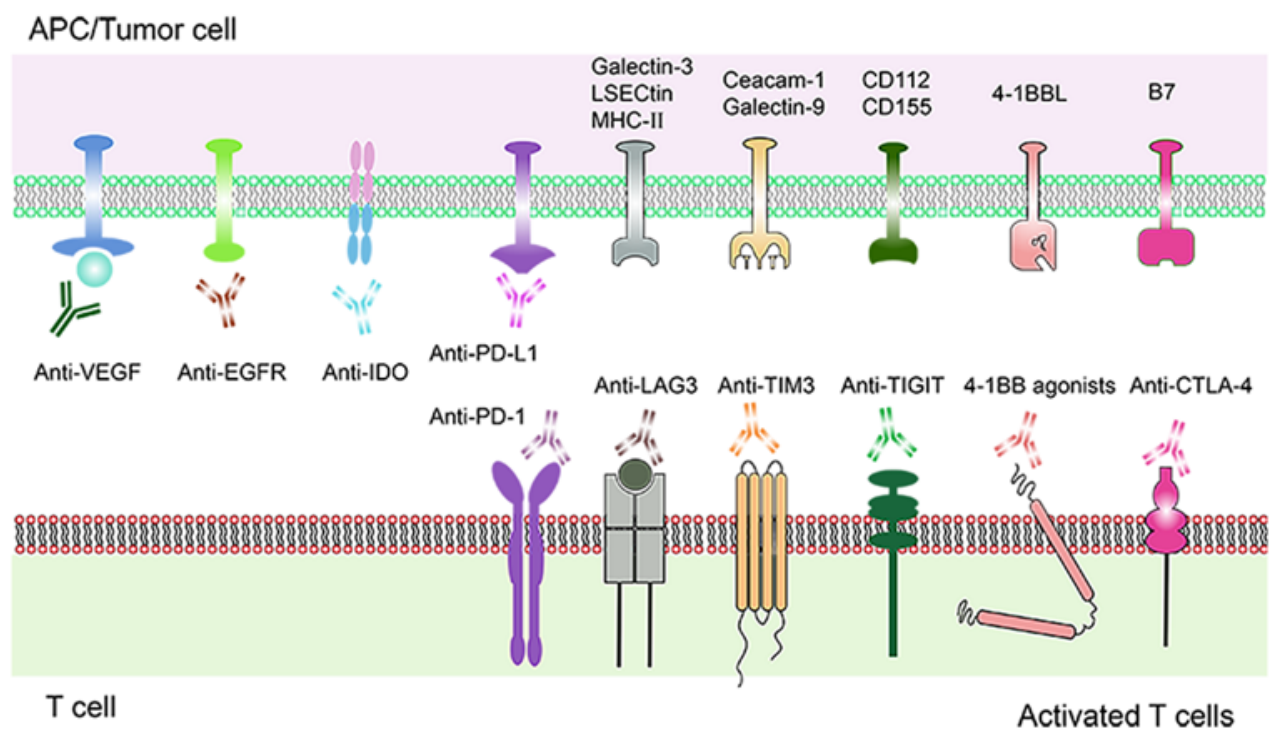

Figure 2. Schematic diagram of a combination therapy comprising molecular targeting drugs and PD-1/PD-L1 inhibitors. Current and emerging molecular targeting drugs. Various molecular targets expressed on T cells and tumor cells are shown. Immune molecular targets such as PD-1, LAG-3, TIM-3, TIGIT, 4-1BB, CTLA-4, IDO bound to their respective specific antibodies, triggering a positive signal to T cells response. Inhibition of VEGF and EGFR mediated angiogenesis. PD-1, programmed cell death protein-1; PD-L1, programmed death protein ligand-1; LAG3, lymphocyte activation gene-3; TIM-3, T cell immunoglobulin mucin 3; TIGIT, T cell immunoreceptor with Ig and ITIM domains; CTLA-4, cytotoxic T-lymphocyte antigen-4; IDO, indoleamine 2,3-dioxygenase; VEGF, vascular endothelial growth factor; EGFR, epidermal growth factor receptor.

inhibitors following EGFR-TKIs pretreatment and chemotherapy (49).

However, a clinical study reports that EGFR inhibitors do not improve sensitivity to PD-1/PD-L1 inhibitors. Phase I/II clinical trials (NCT02039674; keynoteo-021) explored effect Erlotinib or Gefitinib combined with Pembrolizumab for treatment of advanced NSCLC patients with EGFR sensitive mutations. The results showed that combination of these drugs could not improve efficacy and showed no synergistic effect with Pembrolizumab in killing tumor cells (50) (Table III).

Combined application of indoleamine 2,3-dioxygenase (IDO) and $P D-1 / P D-L 1$ inhibitors. IDO is a rate-limiting enzyme that breaks down tryptophan, reduces the number and activity of CD8T cells and is implicated in immunosuppression (Fig. 2). Increase in IDO activity is associated with poor clinical efficacy of PD-1 inhibitors (51). A clinical trial on immunotherapy combined with IDO inhibitors showed high efficacy. A combination therapy of Bms-986205, a potent oral IDO1 inhibitor and Nivolumab resulted in grade 1-2 toxicities with the exception of 3 cases of grade 3 hepatitis, rash and hypophosphatemia (52). Phase II clinical trials of the effect of Indoximod, an IDO inhibitor on melanoma (NCT02073123) (53), pancreatic cancer (NCT02077881) (54) and castrated prostate cancer (NCT01560923) (55) are underway with promising results. The ORR of melanoma patients treated with Indoximod combined with Ipilimumab, Nivolumab or Pembrolizumab was 52\% (56). Epacadostat, an oral drug targeting IDO pathway is in phase I/II clinical trials (NCT 02327078, NCT 02178722) for treatment of multiple malignant tumors. Preliminary results show that ORR for melanoma is 75 and $4 \%$ for colorectal cancer. A combination with Pembrolizumab is relatively safe, however $3 \%$ of patients stopped treatment due to adverse events (57) (Table III).
Combined application of LAG3and PD-1/PD-L1 inhibitors. LAG3 serves a protective role in autoimmunity through direct inhibition of T-helper (Th) cell response by MHCII. LAG3 has a negative regulatory effect on $\mathrm{T}$ cells. Continuous exposure of antigens in tumor microenvironment leads to sustained expression of LAG3 (58) (Fig. 2). LAG3 and PD-1 have synergistic effects, and a previous study has recently explored combined immunotherapy for LAG3 and PD-1 (12).

A combination of anti-LAG3 and PD-1 inhibitors yielded a $100 \%$ tumor clearance in an EG7 lymphoma model, whereas tumor clearance rate in mice treated with PD-1 inhibitors alone was $50 \%$ (59). Targeted inhibition of LAG3 and PD-1 showed significant tumor regression in B16-F10 recurrent melanoma model (60).

These findings show that LAG3 and PD-1 acts synergistically. Bispecific LAG3/PD1 antibodies are being developed to improve efficacy of PD-1 inhibitor monotherapy by inhibiting both LAG3 and PD-1 (61). BMS-986016 was the first anti-LAG3mAb to be developed. The first phase of I/IIa trial has been launched to evaluate efficacy of LAG3 inhibitors combined with Nivolumab in treatment of advanced malignant tumors (NCT01968109) (62). Merck conducted a phase I clinical trial of anti-LAG3 monoclonal antibody (MK-4280) to evaluate safety and tolerance of the drug (63). MK-4280 combined with PD-1 blocker (Pbrobrolizumab) is currently under clinical trial of 70 patients with metastatic solid tumors (NCT02720068) (58) (Table III).

Combined application of Tim-3 and PD-1/PD-L1 inhibitors. Overexpression of Tim-3 is positively associated with poor prognosis of lung, gastric, prostate and cervical cancer (64). Interaction between Tim-3 on effector T cells and Galectin- 9 on tumor cells induces $\mathrm{T}$ cell apoptosis and suppresses immune response (Fig. 2). Blocking Tim-3 enhances T cell proliferation and immune function (65). Tim-3 is highly expressed in 
Table III. Combination of molecular targeting drugs with PD-1/PD-L1 inhibitors.

\begin{tabular}{|c|c|c|c|c|}
\hline Author(s) (year) & Interventions & Primary end point(s) & Results & (Refs.) \\
\hline Zhao et al, 2019 & $\begin{array}{l}\text { PD-L1 inhibitors + VEGFR2 } \\
\text { small molecule inhibitors } \\
\text { (apatinib) }\end{array}$ & $\begin{array}{l}\text { TILs } \\
\text { TAMs, MDSCs, } \\
\text { TGF- } \beta \text {, Tumor growth } \\
\text { Survival }\end{array}$ & $\begin{array}{l}\text { Increased } \\
\text { Hindered } \\
\text { Decreased } \\
\text { Prolonged }\end{array}$ & $(38)$ \\
\hline Reck et al, 2019 & $\begin{array}{l}\text { Anti-PD-L1+ Bevacizuma + } \\
\text { Chemotherapy vs. } \\
\text { Bevacizuma + Chemotherapy }\end{array}$ & $\begin{array}{l}\text { PFS } \\
\text { OS }\end{array}$ & $\begin{array}{l}10.2 \text { months vs. } 6.9 \text { months } \\
13.3 \text { months vs. } 9.4 \text { months }\end{array}$ & $(42)$ \\
\hline Haratani et al, 2017 & $\begin{array}{l}\text { PD-1/PD-L1 inhibitors+ } \\
\text { EGFR-TKIs }\end{array}$ & ORR & $\begin{array}{l}\text { T790M-negative patients }(24 \%) \\
\text { vs. T790M-positive patients }(13 \%)\end{array}$ & $(48)$ \\
\hline Yang et al, 2019 & $\begin{array}{l}\text { Pembrolizumab + Erlotinib } \\
\text { vs. Pembrolizumab+ } \\
\text { Gefitinib }\end{array}$ & $\begin{array}{l}\text { ORR } \\
\text { PFS }\end{array}$ & $\begin{array}{l}41.7 \% \text { vs. } 14.3 \% \\
19.5 \text { months vs. } 1.4 \text { months }\end{array}$ & $(50)$ \\
\hline Siu et al, 2017 & $\begin{array}{l}\text { IDO1 inhibitor } \\
(\text { BMS-986205) + Nivolumab } \\
\text { vs. BMS-986205 }\end{array}$ & Safety & $\begin{array}{l}\text { All treatment-related adverse } \\
\text { events were grade } 1 / 2 \text { except } \\
\text { three grade } 3 \text { toxicities }\end{array}$ & $(52)$ \\
\hline Zakharia et al, 2016 & $\begin{array}{l}\text { IDO inhibitor (Indoximod) + } \\
\text { Ipilimumab, Nivolumab or } \\
\text { Pembrolizumab }\end{array}$ & ORR & $52 \%$ & $(56)$ \\
\hline Hamid et al, 2017 & $\begin{array}{l}\text { IDO inhibitor (Epacadostat) } \\
+ \text { Pembrolizumab }\end{array}$ & ORR & $\begin{array}{l}75 \% \text { of melanoma and } 4 \% \text { of } \\
\text { colorectal cancer }\end{array}$ & $(57)$ \\
\hline Huang et al, 2015 & $\begin{array}{l}\text { Anti-LAG3 + Anti-PD-1 vs. } \\
\text { Anti-PD-1 }\end{array}$ & Tumor clearance & $100 \%$ vs. $50 \%$ & $(59)$ \\
\hline Goding et al, 2013 & $\begin{array}{l}\text { Anti-PD-L1 + anti-LAG-3 } \\
\text { antibodies }\end{array}$ & Tumor area & Reduced & $(60)$ \\
\hline Sakuishi et al, 2010 & $\begin{array}{l}\text { Co-blocking Tim-3 and PD-1 } \\
\text { pathways }\end{array}$ & Tumor Size & Reduced & $(67)$ \\
\hline $\begin{array}{l}\text { Friedlaender et al, } \\
2019\end{array}$ & $\begin{array}{l}\text { Co-blocking Tim-3 and PD-1 } \\
\text { pathways }\end{array}$ & $\begin{array}{l}\text { An ongoing } \\
\text { phase I trials }\end{array}$ & $\begin{array}{l}\text { Anti-tumor study of TIM3 and } \\
\text { PD-L1 inhibitors is under way } \\
\text { (NCT03099109; NCT02608268) }\end{array}$ & $(71)$ \\
\hline Davar et al, 2018 & $\begin{array}{l}\text { Anti-Tim-3(TSR-022)+ } \\
\text { anti-PD-1(TSR-042) }\end{array}$ & SD & $\begin{array}{l}1 \text { case of } 11 \text { evaluable patients } \\
\text { with } 100 \mathrm{mg} \text { dose vs. } 3 \text { cases } \\
\text { of } 20 \text { evaluable patients with } \\
300 \mathrm{mg} \text { dose } \\
3 \text { cases of } 11 \text { evaluable patients } \\
\text { with } 100 \mathrm{mg} \text { dose vs. } 8 \text { cases of } \\
20 \text { evaluable patients with } \\
300 \mathrm{mg} \text { dose }\end{array}$ & (72) \\
\hline Chauvin et al, 2015 & $\begin{array}{l}\text { Anti-TIGIT+ anti-PD-1 vs. } \\
\text { anti-TIGIT vs. anti-PD-1 }\end{array}$ & $\begin{array}{l}\text { NY-ESO-1-specific CD8+ } \\
\text { T cell }\end{array}$ & $\begin{array}{l}\text { Anti-TIGIT+ anti-PD-1>anti- } \\
\text { TIGIT/anti-PD-1 }\end{array}$ & (74) \\
\hline Johnston et al, 2014 & $\begin{array}{l}\text { Anti-TIGIT + anti-PD-L1 vs. } \\
\text { anti-TIGIT vs. anti-PD-L1 }\end{array}$ & $\begin{array}{l}\text { Tumor volume } \\
\text { Percent survival }\end{array}$ & $\begin{array}{l}\text { Anti-TIGIT+ anti-PD-L1 } \\
<\text { anti-TIGIT/anti-PD-L1 } \\
\text { Anti-TIGIT+ anti-PD-L1 } \\
\text { >anti-TIGIT/anti-PD-L1 }\end{array}$ & (76) \\
\hline $\begin{array}{l}\text { Morales-Kastresana } \\
\text { et al, } 2013\end{array}$ & $\begin{array}{l}\text { Combination of anti-4-1BB, } \\
\text { anti-OX40 and anti-PD-L1 }\end{array}$ & $\begin{array}{l}\text { Survival } \\
\text { Tumor-infiltrating } \\
\text { lymphocytes }\end{array}$ & $\begin{array}{l}\text { Extended } \\
\text { Increased }\end{array}$ & $(80)$ \\
\hline Tolcher et al, 2017 & $\begin{array}{l}\text { 4-1BB (Utomilumab) } \\
+ \text { Pembrolizumab }\end{array}$ & $\begin{array}{l}\text { Safety } \\
\text { Activated memory/ } \\
\text { effector CD8+ T cells }\end{array}$ & $\begin{array}{l}\text { Treatment-emergent adverse } \\
\text { events were mostly grades } 1-2 \\
\text { Increased }\end{array}$ & $(83)$ \\
\hline
\end{tabular}


Table III. Continued

\begin{tabular}{|c|c|c|c|c|}
\hline Author(s) (year) & Interventions & Primary end point(s) & Results & (Refs.) \\
\hline Postow et al, 2015 & $\begin{array}{l}\text { Nivolumab + Ipilimumab vs. } \\
\text { Ipilimumab }\end{array}$ & $\begin{array}{l}\text { ORR } \\
\text { The median reduction } \\
\text { in tumor volume }\end{array}$ & $\begin{array}{l}61 \% \text { vs. } 11 \% \\
68.1 \% \text { vs. } 5.5 \%\end{array}$ & $(87)$ \\
\hline Larkin et al, 2015 & $\begin{array}{l}\text { Nivolumab + Ipilimumab vs. } \\
\text { Ipilimumab vs. Nivolumab }\end{array}$ & $\begin{array}{l}\text { PFS } \\
\text { Safety }\end{array}$ & $\begin{array}{l}11.5 \text { months vs. } 2.9 \text { months vs. } \\
6.9 \text { months, } \\
\text { Grade } 3 \text { or } 4 \text { adverse events: } \\
55.0 \% \text { vs. } 27.3 \% \text { vs. } 16.3 \%\end{array}$ & $(88)$ \\
\hline Omuro et al, 2018 & $\begin{array}{l}\text { Nivolumab + Ipilimumab vs. } \\
\text { Ipilimumab vs. Nivolumab }\end{array}$ & $\begin{array}{l}\text { Tolerance } \\
\text { Safety }\end{array}$ & $\begin{array}{l}80 \% \text { vs. } 70 \% \text { vs. } 90 \% \\
\text { Fatigue: } 55 \% \text { vs. } 80 \% \text { vs. } 30 \% \\
\text { Diarrhea: } 30 \% \text { vs. } 70 \% \text { vs. } 10 \%\end{array}$ & (89) \\
\hline
\end{tabular}

PD-1, programmed cell death protein-1; PD-L1, programmed death protein ligand-1.

CD8 positive tumor infiltrating lymphocytes in solid tumor mice (66). Tim-3 (+) PD-1 (+) TILs is a severe failure phenotype, which does not proliferate to produce IL-2, TNF and IFN- $\gamma$ (67). A previous study reported that blocking Tim-3 and PD-1 pathways effectively controls tumor growth through synergistic activity (67). A combination of Tim-3 inhibitor and PD-1 inhibitor in mice with lung cancer upregulates expression of TILs (68). Administration of PD-1 inhibitors only results in drug resistance promoting tumor progression. Co-administration with Tim-3 inhibitor restores anti-tumor effect and increases survival time $(69,70)$. These findings imply that Tim-3 inhibitor may increase IFN- $\gamma$ levels and increase $\mathrm{T}$ cell proliferation (13). Co-administration of Tim-3 and PD-1 shows synergistic effect on anti-tumor cells. An anti-tumor study on combination of Tim-3 and PD-L1 inhibitors is underway (NCT03099109 and NCT02608268) (71). Currently, only Phase I results have been reported (72) on Tim-3 antibodies (TSR-022) and PD-1 inhibitors (TSR-042) combination therapy. A total of 39 patients with NSCLC who were treated with PD-1 inhibitors were further treated with TSR-042, at a fixed dose of $500 \mathrm{mg}$ combined with TSR-022 $100 \mathrm{mg}$ (14 cases)/3 weeks and $300 \mathrm{mg}$ ( 25 cases)/3 weeks. Of the 11 patients who received a dose of $100 \mathrm{mg}$ TSR-022, 1 case was partially responsive (PR) and 3 cases were stable disease (SD). For 20 patients who received a dose of $300 \mathrm{mg}$ TSR-022, 3 cases were PR and 8 cases were SD. All reactions occurred in PD-L1 positive patients. Only 12 PD-L1 positive patients were analyzed, 4 were PR and 6 were SD (the 2 other patients were not specifically identified). The current dose was well tolerated. The disease control rate was $55 \%$ and the disease control rate was $83 \%$ in PD-L1 positive subgroups (72) (Table III).

Combined application of TIGIT and PD-1/PD-L1 inhibitors. TIGIT is a member of the immunoglobulin superfamily which is exclusively expressed in lymphocytes. When it binds to its ligand CD155, TIGIT inhibits $\mathrm{T}$ cell proliferation and IFN $-\gamma$ production. Therefore, activation of TIGIT pathway induces tumor immune escape (73) (Fig. 2). Co-blocking of PD-1/PD-L1 and TIGIT pathways restores the function of failed CD8+T cells. In patients with melanoma, co-blocking of TIGIT and PD-1 increases the proliferation of CD8 TILs, cytogenesis and degranulation (74). In a mouse CT26 tumor model, co-inhibition of TIGIT and PD-L1 enhances CTL functions and restores CD8+T functions (75). Combination therapy induces tumor regression and tumor antigen-specific protective memory (76). TIGIT synergized with other co-suppressor molecules PD-1 and Tim-3 to inhibit effector $\mathrm{T}$ cell response and promote $\mathrm{T}$ cell dysfunction. Therefore, inhibiting TIGIT with PD-1 or Tim-3 may promote anti-tumor immunity and induce tumor regression (77). Phase I clinical trials are underway to evaluate the safety and efficacy of anti-TIGIT monoclonal antibodies (OMP-31M32; NCT 03119428) (78) (Table III).

Combined application of 4-1BB (CD137) agonists and $P D-1 / P D-L 1$ inhibitors. 4-1BB (CD137) is an inducible costimulatory receptor. On binding to its ligand (4-1BBL), it triggers the proliferation and activation of immune cells (79) (Fig. 2). A combination of PD-1 inhibitors and 4-1BB agonists has a strong synergistic effect. The combination also exerts significant effects on mice cancer models with poor immunogenicity (80). Utomilumab (PF-05082566) is a human monoclonal antibody that stimulates 4-1BB (81). As an accelerator of the immune system, Utomilumab has been investigated in clinical research (82). A study has shown that the level of activated memory/effector $\mathrm{CD} 8+\mathrm{T}$ cells in peripheral blood increases following treatment with a combination of Utomilumab (0.45-5.0 mg/kg) and Pembrolizumab $(2 \mathrm{mg} / \mathrm{kg})$. The combination is safe and well tolerated, consistent with the expected side effects of Pembrolizumab alone (83). Urelumab (BMS-663513) was the first anti-4-1BB drug to enter clinical trials. Studies show that a combination use of Urelumab and Nivolumab is well tolerated. The overall response rate of metastatic melanoma was $47 \%$ (84) (Table III).

Combined application of cytotoxic T lymphocyte associated protein 4 (CTLA-4) and PD-1/PD-L1 inhibitors. Ipilimumab (Anti-CTLA-4) is an immunomodulatory monoclonal antibody that targets cell surface antigen CTLA-4 as an ICL (85) (Fig. 2). The use of CTLA-4 and PD-1 inhibitors, either as 
singly or as combinations, has been approved by US FDA for the treatment of metastatic melanoma (86).

In a phase II clinical study, the objective response rate of patients with advanced melanoma who received Nivolumab + Ipilimumab was significantly higher than that of patients who received Ipilimumab + placebo (61 vs. 11\%). In the Nivolumab + Ipilimumab group, $22 \%$ of the patients showed complete response (87). A clinical study has shown that Nivolumab combined with Ipilimumab yields a PFS of 11.5 months, whereas the PFS of Ipilimumab or Nivolumab alone was 2.9 and 6.9 months, respectively. The probability of treatment-related grade 3 or 4 adverse events in Nivolumab group, Ipilimumab group and combination group was 16.3, 27.3 and $55.0 \%$, respectively (88). Another clinical study has explored the safety and tolerance of Nivolumab with or without Ipilimumab in the treatment of recurrent glioblastoma. It has been reported that the tolerance of Nivolumab $3 \mathrm{mg} / \mathrm{kg}$ group exceeds that of Nivolumab $1 \mathrm{mg} / \mathrm{kg}+$ Ipilimumab $3 \mathrm{mg} / \mathrm{kg}$ and Nivolumab $3 \mathrm{mg} / \mathrm{kg}+$ Ipilimumab $1 \mathrm{mg} / \mathrm{kg}$ subgroups (90 vs. 70 vs. $80 \%$, respectively). Fatigue and diarrhea were the most common treatment-related adverse events associated with the aforementioned drugs (30 vs. 80 vs. $55 \%$; 10 vs. 70 vs. $30 \%$, respectively) and no other side effects were observed. Tolerance to the combination was negatively influenced by the dose of Ipilimumab (89) (Table III).

\section{Combination of chemotherapy with PD-1/PD-L1 inhibitors}

Chemotherapy usually kills cancer cells by targeting their DNA synthesis and replication (90). It also promotes the presentation of tumor antigens following cancer cell death, activates tumor specific T cells, facilitates DCs maturation, stimulates type I interferon response and eliminates bone marrow-derived immunosuppressive cells (91). Appropriate combination of chemotherapeutic drugs and PD-1/PD-L1 inhibitors can enhance the efficacy of PD-1 blockers and produce a more sustained anti-tumor response, especially in tumors with poor immunogenicity and sensitivity to chemotherapy. A study has shown that Pembrolizumab combined with pemetrexed/carboplatin enhances improves symptoms of metastatic non-squamous NSCLC and has been approved by US FDA (92). Application of Pembrolizumab in combination with pemetrexed and platinum increases the PFS of metastatic NSCLC (93). For untreated patients with metastatic squamous NSCLC, the PFS and OS of Pembrolizumab combined treatment group versus the placebo group were 6.4 months vs. 4.8 months and 15.9 months vs. 11.3 months, respectively. The risk of death decreased by $36 \%$ and the risk of disease progression or death reduced by $44 \%$ in the Pembrolizumab combined treatment group (94) (Table IV).

\section{Combination of radiotherapy with PD-1/PD-L1 inhibitors}

Radiotherapy (RT) has profound immunological effects. Basic research studies have demonstrated that RT can improve the efficacy of PD-1 inhibitors (95). Cancer cells can be killed by radiation. RT activates the immune system by triggering the release of tumor antigens (96). Basic research and clinical trials have revealed that RT synergizes with immunotherapy when applied together $(97,98)$. A study has shown that PD-1 inhibitors combined with RT can activate CTLs and reduce immunosuppressive cells (99). A combination of RT and PD-1/PD-L1 inhibitors significantly improves the survival rate and reduces the tumor volume in mice (100). Compared with the control group, co-treatment of RT and PD-1 significantly increased the expression of PD-L1, CD8+T cells and interferon- $\gamma$ in tumor cells (101). Clinical studies have provided evidence that anti-PD-1 therapy can significantly improve the control rate and OS rate of patients with melanoma brain metastasis who received stereotactic radiotherapy (102). Clinical trials of the efficacy of Nivolumab combined with RT in the treatment of NSCLC (NCT02768558) and glioblastoma (NCT02617589) are under way (103).

Immunotherapy amplifies the rare systemic effects of radiotherapy, while radiotherapy renders immune-excluded tumors quickly responsive to immunotherapy (104). MDSCs have been implicated in development of radioresistance. Accumulation of MDSC in the tumor microenvironment promotes tumor relapse by directly affecting tumor cell survival and indirectly affecting local $\mathrm{T}$ cell suppression (105). A combination of irradiation (IR) and anti-PD-L1 therapy enhanced the activation of CD8+ T cells and inhibition of TUBO tumor growth. CD8+ T cells induce the apoptosis of MDSCs through TNF- $\alpha$ following combination therapy (95). PD-L1 is upregulated in the tumor microenvironment following IR. IR-induced increases in tumor-infiltrating lymphocytes (TILs) and upregulation of PD-L1 could provide an opportunity for PD-L1 blockade (106). The combination of IR and anti-PD-L1 treatment optimizes the tumor immune microenvironment and results in tumor regression (95). Local radiotherapy significantly adds to the systemic efficacy of immunotherapy. Combining single-site stereotactic body radiotherapy (SBRT) with pembrolizumab improves response rates in metastatic NSCLC. PD-L1-negative patients benefited from SBRT (107). This study also suggested that the way to improve the effect of immunotherapy was to treat with local radiotherapy to synergize the local and systemic effects of both modalities. Immunotherapy increased the local effect of radiotherapy in all treated sites. Radiotherapy suppresses the tumor burden allowing immunotherapy better to eliminate micro-metastatic disease (108). In addition, a study demonstrated that higher single doses of RT from 12-18 Gy blunt the efficacy of anti-tumor immunity. They also reduce IFN- $\beta$ production and abrogate DC-mediated CD8+T-cell priming, suggesting that RT doses below 12 Gy may be more immunogenic (109). Another study confirmed that a single dose of $15 \mathrm{~Gy}$ irradiation results in higher tumor immune cell infiltration than a fractionated (3 Gy x 5) schedule (110). The differences in the above results might be due to differences in the genetic backgrounds of mice, immune competence and immunogenicity of models and radiosensitivity of cell lines (111) (Table IV).

\section{Combination of intestinal microflora with PD-1/PD-L1 inhibitors}

Intestinal microflora influences the effects of immunotherapy in cancers. A previous study reported that oral Bifidobacterium can significantly decrease the growth rate of melanoma, promote the maturation of dendritic cells and 
Table IV. Combination of chemotherapy or radiotherapy with PD-1/PD-L1 inhibitors.

\begin{tabular}{|c|c|c|c|c|}
\hline Author(s) (year) & Interventions & Primary end point(s) & Results & (Refs.) \\
\hline Langer et al, 2016 & $\begin{array}{l}\text { Pembrolizumab + Chemotherapy } \\
\text { vs. Chemotherapy }\end{array}$ & $\begin{array}{l}\text { ORR } \\
\text { The incidence of grade } 3 \text { or } \\
\text { worse treatment-related adverse } \\
\text { events }\end{array}$ & $\begin{array}{l}55 \% \text { vs. } 29 \% \\
39 \% \text { vs. } 26 \%\end{array}$ & (92) \\
\hline Gandhi et al, 2018 & $\begin{array}{l}\text { Pembrolizumab + Chemotherapy } \\
\text { vs. Placebo + Chemotherapy }\end{array}$ & $\begin{array}{l}\text { Rate of Overall survival at } \\
12 \text { months } \\
\text { PFS }\end{array}$ & $\begin{array}{l}69.2 \% \text { vs. } 49.4 \% \\
8.8 \text { months vs. } 4.9 \text { months }\end{array}$ & (93) \\
\hline Paz-Ares et al, 2018 & $\begin{array}{l}\text { Pembrolizumab + Chemotherapy } \\
\text { vs. Placebo + Chemotherapy }\end{array}$ & $\begin{array}{l}\text { PFS } \\
\text { OS }\end{array}$ & $\begin{array}{l}6.4 \text { months vs. } 4.8 \text { months } \\
15.9 \text { months vs. } 11.3 \text { months }\end{array}$ & (94) \\
\hline Deng et al, 2014 & $\begin{array}{l}\text { Irradiation (IR) + Anti-PD-L1 vs. } \\
\text { Anti-PD-L1 vs. IR }\end{array}$ & $\begin{array}{l}\text { The percentage of MDSCs in } \\
\text { the total CD } 45+\text { cell population }\end{array}$ & $\begin{array}{l}25.59 \pm 10.26 \mathrm{~mm} \text { vs. } \\
587.3 \pm 169.1 \mathrm{~mm} \text { vs. } \\
402.8 \pm 76.73 \mathrm{~mm} \\
0.38 \pm 0.16 \% \mathrm{vs} . \\
7.33 \pm 2.22 \% \text { vs. } \\
4.78 \pm 2.49 \%\end{array}$ & $(95)$ \\
\hline Sharabi et al, 2015 & XRT + Anti-PD-1 & $\begin{array}{l}\text { Tumor volume } \\
\text { T-cell infiltration }\end{array}$ & $\begin{array}{l}\text { Inhibited } \\
\text { Increased }\end{array}$ & (99) \\
\hline Dovedi et al, 2014 & RT + PD-1/PD-L1 blocking & $\begin{array}{l}\text { Tumor volume } \\
\text { Percent survival }\end{array}$ & $\begin{array}{l}\text { Inhibited } \\
\text { Improved }\end{array}$ & $(101)$ \\
\hline Ahmed et al, 2016 & $\begin{array}{l}\text { Stereotactic radiation }+ \\
\text { Anti-PD-1 }\end{array}$ & $\begin{array}{l}\text { local lesions control rates at } \\
6 \text { and } 12 \text { months } \\
\text { OS rates at } 6 \text { and } 12 \text { months }\end{array}$ & $\begin{array}{l}91 \text { and } 85 \% \\
78 \text { and } 55 \%\end{array}$ & $(102)$ \\
\hline
\end{tabular}

PD-1, programmed cell death protein-1; PD-L1, programmed death protein ligand-1.

production of IFN- $\gamma$ and enhance the anti-tumor effect of PD-1 inhibitors (112). The abnormal composition of intestinal flora may affect the response of patients to cancer immunotherapy (113). Transplantation of fecal bacteria improved the anti-tumor effect of PD-1 inhibitors (114). A study has shown that the clinical response of PD-1 inhibitors is dependent on the relative abundance of Akkermansia muciniphila. Oral supplementation of Akkermansia muciniphila restores the efficacy of PD-1 inhibitors in an IL-12-dependent manner (115). In another study, intestinal microflora regulated the response of anti-PD-1 immunotherapy to melanoma patients (116).

Patients with abundant beneficial intestinal bacteria (Ruminococcaceae/Faecalibacterium) have improved antigen presentation, effector $\mathrm{T}$ cells function in peripheral and tumor microenvironment and strong anti-tumor immune response (117). By contrast, the intestinal harmful bacteria (Bacteroidales) weakened antigen presentation and impaired anti-tumor immune response $(118,119)$. Response to PD-1 inhibitors is influenced by the composition of intestinal flora, but not to oral flora (120). Other studies suggest that patients with melanoma responsive to Nivolumab were rich in Fecalibacterium prausnitzii, Bacteroides thetaiotamicron, B. longum, C. aerofaciens and E. faecium. Patients who responded well to Pembrolizumab were rich in intestinal Dorea formicogenerans $(121,122)$ (Table V).

\section{Combination of Traditional Chinese Medicine with PD-1/PD-L1 inhibitors}

Diosgenin is a natural steroidal saponin (123). A combination of diosgenin with PD-1 inhibitor suppresses tumor growth, increased $\mathrm{T}$ cell infiltration and IFN- $\gamma$ expression in tumor tissues. Diosgenin stimulates the immune cells thereby improving the response rate and therapeutic effect of PD-1 inhibitors (124). Diosgenin treatment downregulates intestinal Bacteroidetes but upregulated Clostridiales, Lactobacillus and Sutterella (124).

Icariin possesses a variety of pharmacological and biological activities. Icaritin is now under clinical trial for the treatment of PD-L1 positive advanced liver cancer (NCT03236649) and advanced breast cancer (NCT01278810). Pre-clinal studies have shown that Icaritin can effectively reduce the tumor load of B16F10 melanoma and MC38 colorectal cancer in mice and its therapeutic effect is T cell-dependent. It increased CD8 $\mathrm{T}$ cell infiltration and the number of effector memory $\mathrm{T}$ cells. A combination of PD-1 inhibitor and Icaritin significantly suppressed tumor growth (125).

Rhus verniciflua Stokes (RVS) has been shown to contain a large number of bioactive phytochemicals, including alkaloids, polyphenols and flavonoids, which block the interaction between PD-1/PD-L1 and CTLA-4/CD80. Thus, RVS might be used as an immune checkpoint blocker (126). 
Table V. Combination of intestinal microflora with PD-1/PD-L1 inhibitors.

\begin{tabular}{|c|c|c|c|c|}
\hline Author(s) (year) & Interventions & Primary end point(s) & Results & (Refs.) \\
\hline Sivan, 2015 & Bifidobacterium + Anti-PD-L1 & $\begin{array}{l}\text { Tumor volume } \\
\text { IFN- } \gamma, \text { DCs }\end{array}$ & $\begin{array}{l}\text { Reduced } \\
\text { Increased }\end{array}$ & $(112)$ \\
\hline Routy et al, 2018 & $\begin{array}{l}\text { A. muciniphila + Anti-PD-1 vs. } \\
\text { Anti-PD-1 }\end{array}$ & $\begin{array}{l}\text { PR } \\
\text { SD } \\
\text { PD } \\
\text { Tumor size }\end{array}$ & $\begin{array}{l}69 \% \text { vs. } 31 \% \\
58 \% \text { vs. } 42 \% \\
34 \% \text { vs. } 66 \% \\
\text { A. muciniphila +Anti-PD-1< } \\
\text { Anti-PD-1 }\end{array}$ & $(115)$ \\
\hline Frankel et al, 2017 & $\begin{array}{l}\text { Ipilimumab + Nivolumab vs. } \\
\text { Pembrolizumab }\end{array}$ & $\begin{array}{l}\text { RECIST response } \\
\text { SD }\end{array}$ & $\begin{array}{l}67 \% \text { vs. } 23 \% \\
8 \% \text { vs. } 23 \%\end{array}$ & $(121)$ \\
\hline Matson, 2018 & $\begin{array}{l}\text { Fecal material from three } \\
\text { responder patient donors + } \\
\text { Anti-PD-L1(R) vs. Fecal } \\
\text { material from three } \\
\text { non-responder patient } \\
\text { donors + Anti-PD-L1(NR) }\end{array}$ & $\begin{array}{l}\text { IFN- } \gamma \text {, Tumor-infiltrating } \\
\text { specific CD8+ T cells } \\
\text { Tumor volume }\end{array}$ & $\begin{array}{l}\mathrm{R}>\mathrm{NR} \\
\mathrm{R}<\mathrm{NR}\end{array}$ & $(122)$ \\
\hline
\end{tabular}

PD-1, programmed cell death protein-1; PD-L1, programmed death protein ligand-1.

Ganoderma lucidum reduces the proportion of PD-1 positive cells in B lymphocytes. It can, therefore, be used to develop a new type of immunomodulator for the prevention and treatment of cancer (127). The combination of Ganoderma lucidum and paclitaxel inhibits the expression of immune checkpoints (PD-1 and Tim-3) and restored TILs. The combination regulates the development of 4T1-breast cancer in mice (128) (Table VI).

\section{Conclusion and future perspectives}

The anti-tumor response rate of PD-1 inhibitors is low. Patients sensitive to PD-1/PD-L1 inhibitors develop drug resistance, tumor recurrence and disease progression and the mortality rate of patients with advanced tumor stages is high. A study has reported that patients with melanoma sensitive to anti-PD-L1 antibody treatment show increased levels of interferon- $\gamma$ and related genes in blood prior to treatment (129). Anti-PD-1 therapy downregulates expression of IFN receptor-related genes and MHC I and upregulates inhibitory receptors on the surface of T cells (10). Furthermore, the inhibitory receptors inhibit the cytotoxic activity of $\mathrm{T}$ cells and these effects can be attributed to drug resistance against ICIs. Several basic and clinical studies are exploring effective combination and sequence of PD-1/PD-L1 inhibitors and other anti-tumor therapies to induce tumor cell immunogenicity and improve effectiveness of anti-tumor effect of PD-1/PD-L1 inhibitors. These advances will provide effective therapies for patients who are unresponsive to current treatment regimens. However, development of these combination therapies possesses several challenges.

Development of effective antineoplastic therapy should consider medical costs and adverse reactions for each treatment. Therefore, it is necessary to determine predictive biomarkers for individualized therapy, so as to predict efficacy and adverse reactions of PD-1/PD-L1 inhibitors. At present, some patients are not sensitive to PD-1/PD-L1 inhibitors. Lack of biomarkers for predicting response rate limits the effectiveness of clinical treatment strategies, thus there is need to screen novel biomarkers for predicting immunotherapy responses in patients.

In order to increase the proportion of patients benefiting from PD-1/PD-L1 inhibitors, studies should explore potential predictive biomarkers for anti-tumor treatment. PD-L1 expression is a potential biomarker for predicting effectiveness of PD-1/PD-L1 immunotherapy on patients with cancer thus identifying patients who may benefit from immunotherapy. Expression of PD-L1 is associated with several TILs and activated tumor antigen-specific $\mathrm{T}$ cells induces expression of PD-L1 $(130,131)$. However, expression of PD-L1 in tumor tissues is heterogeneous and changes with tumor treatment $(132,133)$. Several staining antibodies are used in immunohistochemical methods (IHC) to detect PD-L1 expression and the staining techniques (manual and automated) vary (134-136). Currently, effectiveness of PD-L1 detection as an anti-tumor immune response index is still controversial. The association between the expression of PD-1 or PD-L1 at the tumor site and disease outcome varies in patients with different tumors (137-139). Therefore, it is difficult to achieve consistent results with PD-L1 detection, hindering application of anti-PD-1/PD-L1 therapy as precision medicine.

TIL in tumor tissue demonstrates the presence of immune response by the body (140). TIL positive + PD-L1 positive group show improved PD-1/PD-L1 inhibitor immune response compared with TIL negative + PD-L1 positive group. This implies that the number of TIL can predict efficacy of PD-1/PD-L1 inhibitors (141). TIL mainly infiltrates into tumor nests, tumor stroma and tumor invasive margins of tumor tissues and different parts have different associations 
Table VI. Combination of Traditional Chinese Medicine with PD-1/PD-L1 inhibitors.

\begin{tabular}{|c|c|c|c|c|}
\hline Author(s) (year) & Interventions & Primary end point(s) & Results & (Refs.) \\
\hline Dong et al, 2018 & $\begin{array}{l}\text { Diosgenin + anti-PD-1 vs. } \\
\text { diosgenin vs. anti-PD-1 }\end{array}$ & Mean tumor weigh & $\begin{array}{l}1,980.00 \pm 861.22 \mathrm{mg} \text { vs. } \\
3,203.33 \pm 641.43 \mathrm{mg} \text { vs. } \\
2,530.00 \pm 584.04 \mathrm{mg}\end{array}$ & $(124)$ \\
\hline Hao et al, 2019 & $\begin{array}{l}\text { Icariin + anti-PD-1 + anti- } \\
\text { CTLA-4 vs. anti-PD-1 + anti- } \\
\text { CTLA-4 }\end{array}$ & Average inhibition rates & $65 \%$ vs. $34.2 \%$ & $(125)$ \\
\hline Li et al, 2019 & Rhusverniciflua Stokes & $\begin{array}{l}\text { The IC50 of blocking } \\
\text { PD-1/PD-L1 interaction }\end{array}$ & $26.22 \mu \mathrm{g} / \mathrm{ml}$ & $(126)$ \\
\hline Wang et al, 2019 & Ganoderma lucidum & PD-1 & Decreased & $(127)$ \\
\hline Su et al, 2018 & Ganoderma lucidum + Paclitaxel & $\begin{array}{l}\text { Tumor weight } \\
\text { Tumor infiltration lymphocytes } \\
\text { PD-1, Tim-3 }\end{array}$ & $\begin{array}{l}\text { Decreased } \\
\text { Increased } \\
\text { Inhibited }\end{array}$ & $(128)$ \\
\hline
\end{tabular}

PD-1, programmed cell death protein-1; PD-L1, programmed death protein ligand-1.

with therapeutic effects (142). Therefore, it is necessary to further determine the association between the quantity and quality of TIL and other infiltrating immune cells and tumor immune response. In addition, local radiotherapy is effective in inducing inflammation, which may benefit patients without sustained immune response (99). Radiotherapy should not be used in patients with significant tumor infiltration, as this may impair the ongoing immune response $(143,144)$. Effects of different therapies on immune response should be considered when designing combination therapies with chemotherapy and targeted therapy.

Mismatch repair (MMR) is a set of susceptibility genes isolated from hereditary non-polyposis colorectal cancer. Mutations in these gene leads to loss of mismatch repair function, resulting in microsatellite instability (MSI) which is prone to tumors (145). Microsatellite instability high (MSI-H) attracts tumor-infiltrating lymphocytes (TILs) and upregulates PD-L1 expression in tumor epithelial cells (146). MMR deficiency (MMR-D) type solid tumors have more tumor neoantigens to enhance anti-tumor immune response and show an improved response to PD-1 monoclonal antibody, thereby improving immune suppression and restoring anti-tumor immunity (147). MMR-D is a predictor for anti-PD-D efficacy. However, MMR-D only occurs in a small number of patients. Further pre-clinical and clinical research should be performed before clinical application.

The therapeutic effect of PD-1 inhibitors is high in patients with a high mutation load of tumor mutation burden (TMB). Tumor cells with high TMB expression have higher levels of neoantigens, which stimulate a stronger anti-tumor immune response (148). TMB and PD-L1 have similar predictive function. However, TMB is not associated with PD-L1 expression. TMB is an important and independent predictive biomarker, which can predict the effectiveness of ICIs (149).

Further studies should explore ways to alleviate side effects of immunotherapy. Resistance of malignant tumors against PD-1/PD-L1 inhibitors can be overcome by use of combination therapy of PD-1/PD-L1 inhibitors (150).
Notably, a combination of anti-PD-1/PD-L1 therapy is more effective compared with use of anti-PD-1/PD-L1 inhibitors alone. However, combination therapy is associated increased side effects (88). A study revealed that patients younger than 65 years old benefit more from nivolumab plus ipilimumab treatment than patients older than 65 years old. Therefore, combination therapies with ICIs should be carefully chosen for patients $>65$ years of age (151). Goals for treatment of patients with advanced cancer is usually palliative, prolonging survival, controlling symptoms and improving quality of life. Therefore, studies should explore combination therapies with ICIs and fully understand the toxic effects of immunotherapy, chemotherapy and radiotherapy to make sound treatment decision. Side effects such as immune disorders caused by ICIs are called immune-related adverse events. Common adverse reactions include diarrhea, fatigue, itching, rash, nausea and loss of appetite. Severe adverse reactions include severe diarrhea, colitis, myocarditis and cardiac insufficiency, liver dysfunction, pneumonia and glomerulonephritis $(88,152,153)$. Serious side effects may require discontinuation of treatment, although patients may have an immune response thereafter. Intravenous corticosteroids or immunosuppressive drugs should be given if necessary. Some treatment-related autoimmune responses, such as rashes, are associated with improved prognosis (154). This implies that occurrence of adverse reactions is manifested by activation of immune system and represents action of PD-1/ PD-L1 inhibitor, which eliminates tumors. There is an overlap between autoimmune reaction and anti-tumor immune reaction. Further studies should be performed to explore adverse drug reactions associated with immunotherapy.

Clinical application of molecular targeted drugs is associated with challenges such as acquired drug resistance and side effects which need to be minimized. Several studies are exploring the development of molecular targeted drugs with higher efficiency and fewer side effects $(155,156)$. Studies exploring sequence, dosage and safety of PD-1 inhibitors and EGFR should be performed (157,158). Development of combination therapies will improve efficacy and reduce side effects 
of molecular targeted drugs. A number of clinical studies on combination therapies between chemotherapy and radiotherapy with immunotherapy are underway. An open-label, randomized phase 3 study showed that pembrolizumab+chemotherapy significantly improved OS in the total population. The data support the use of pembrolizumab+platinum $+5-\mathrm{FU}$ as new first-line standards of care for recurrent/metastatic head and neck squamous cell carcinoma (NCT0235803) (159). In the KEYNOTE-189 and KEYNOTE-407 studies (phase III), PFS and OS were significantly longer in patients treated with pembrolizumab and chemotherapy compared with those in patients treated with chemotherapy alone $(93,94)$. Anti-PD-1 therapy enhances the efficacy of radiotherapy in metastatic gastric cancer treatment by increasing the $\mathrm{CD} 8^{+} \mathrm{T}$ cell/effector regulatory $\mathrm{T}$ cell ratio in TILs (160). Another study showed that patients with metastatic NSCLC treated with nivolumab or pembrolizumab+radiotherapy did not have increased grade $3 / 4$ immune-related adverse events (161). The combination of chemotherapy and radiotherapy with PD-1/PD-L1 inhibitors induces lasting immune response in treatment of tumors when other treatment strategies fail.

Despite a significant number of basic and ongoing clinical trials aimed at improving effectiveness of combination therapies, intestinal flora combined with PD-1/PD-L1 inhibitors is a novel approach for cancer treatment. However, differences between basic and clinical trial results occur due to high variability of bacteria in intestinal tract and the effects produced by bacteria in the laboratory. Less diverse bacteria used in basic trials may not fully represent the complicated environment in the intestinal tract. Therefore, further studies should explore the mechanism of intestinal flora, side effects, optimal dosage and species for human use for development of effective combination therapies.

\section{Acknowledgements}

Not applicable.

\section{Funding}

This study was funded by the National Natural Science Foundation of China (grant no. 81973728) and Natural Science Foundation of Tianjin (grant no. 18JCZDJC36600).

\section{Availability of data and materials}

Not applicable.

\section{Authors' contributions}

All authors contributed to the content development of this article. XK conceived and designed the study. PL, CL and YG reviewed literature and collated appropriate information. $\mathrm{XK}$, YY, YP, FW, ZB and XD wrote the manuscript. HS generated figures and tables. JM reviewed and edited the manuscript. All authors approved the final manuscript

\section{Ethics approval and consent to participate}

Not applicable.

\section{Patient consent for publication}

Not applicable.

\section{Competing interests}

Authors declare that they have no competing interests.

\section{References}

1. Duan J, Cui L, Zhao X, Bai H, Cai S, Wang G, Zhao Z, Zhao J, Chen S, Song J, et al: Use of immunotherapy with programmed cell death 1 vs programmed cell death ligand 1 inhibitors in patients with cancer: A systematic review and meta-analysis. JAMA Oncol 6: 375-384, 2020.

2. Chiu YM, Tsai CL, Kao JT, Hsieh CT, Shieh DC, Lee YJ, Tsay GJ, Cheng KS and Wu YY: PD-1 and PD-L1 up-regulation promotes T-cell apoptosis in gastric adenocarcinoma. Anticancer Res 38: 2069-2078, 2018

3. Wang DY, Salem JE, Cohen JV, Chandra S, Menzer C, Ye F, Zhao S, Das S, Beckermann KE, Ha L, et al: Fatal toxic effects associated with immune checkpoint inhibitors: A systematic review and meta-analysis. JAMA Oncol 4: 1721-1728, 2018.

4. Jin HT, Ahmed R and Okazaki T: Role of PD-1 in regulating T-cell immunity. Curr Top Microbiol Immunol 350: 17-37, 2011.

5. Ribas A and Wolchok JD: Cancer immunotherapy using checkpoint blockade. Science 359: 1350-1355, 2018.

6. Sanmamed MF and Chen L: A paradigm shift in cancer immunotherapy: From enhancement to normalization. Cell 175: 313-326, 2018.

7. Ribas A,Dummer R, Puzanov I, VanderWalde A, Andtbacka RHI, Michielin O, Olszanski AJ, Malvehy J, Cebon J, Fernandez E, et al: Oncolytic virotherapy promotes intratumoral $\mathrm{T}$ cell infiltration and improves anti-PD-1 immunotherapy. Cell 170: 1109-1119.e10, 2017.

8. Nowicki TS, Hu-Lieskovan S and Ribas A: Mechanisms of resistance to PD-1 and PD-L1 blockade. Cancer J 24: 47-53, 2018.

9. Torrejon DY, Abril-Rodriguez G, Champhekar AS, Tsoi J, Campbell KM, Kalbasi A, Parisi G, Zaretsky JM, Garcia-Diaz A, Puig-Saus C, et al: Overcoming genetically based resistance mechanisms to PD-1 blockade. Cancer Discov 10: 1140-1157, 2020.

10. Zaretsky JM, Garcia-Diaz A, Shin DS, Escuin-Ordinas H, Hugo W, Hu-Lieskovan S, Torrejon DY, Abril-Rodriguez G, Sandoval S, Barthly L, et al: Mutations associated with acquired resistance to PD-1 blockade in melanoma. N Engl J Med 375: 819-829, 2016.

11. Li J, Chen Y, Shi X, Le X, Feng F, Chen J, Zhou C, Chen Y, Wen $\mathrm{S}$, Zeng $\mathrm{H}$, et al: A systematic and genome-wide correlation meta-analysis of PD-L1 expression and targetable NSCLC driver genes. J Thorac Dis 9: 2560-2571, 2017.

12. Anderson AC, Joller N and Kuchroo VK: Lag-3, Tim-3, and TIGIT: Co-inhibitory receptors with specialized functions in immune regulation. Immunity 44: 989-1004, 2016.

13. Koyama S, Akbay EA, Li YY, Herter-Sprie GS, Buczkowski KA, Richards WG, Gandhi L, Redig AJ, Rodig SJ, Asahina H, et al: Adaptive resistance to therapeutic PD-1 blockade is associated with upregulation of alternative immune checkpoints. Nat Commun 7: 10501, 2016.

14. Jenkins RW, Barbie DA and Flaherty KT: Mechanisms of resistance to immune checkpoint inhibitors. Br J Cancer 118: 9-16, 2018.

15. Garg AD and Agostinis P: Cell death and immunity in cancer: From danger signals to mimicry of pathogen defense responses. Immunol Rev 280: 126-148, 2017.

16. Cai J, Lin Y, Zhang H, Liang J, Tan Y, Cavenee WK and Yan G: Selective replication of oncolytic virus M1 results in a bystander killing effect that is potentiated by Smac mimetics. Proc Natl Acad Sci SA 114: 6812-6817, 2017.

17. VanSeggelen H, Tantalo DG, Afsahi A, Hammill JA and Bramson JL: Chimeric antigen receptor-engineered T cells as oncolytic virus carriers. Mol Ther Oncolytics 2: 15014, 2015.

18. Coffin R: Interview with Robert Coffin, inventor of T-VEC: The first oncolytic immunotherapy approved for the treatment of cancer. Immunotherapy 8: 103-106, 2016. 
19. Andtbacka RH, Kaufman HL, Collichio F, Amatruda T, Senzer N, Chesney J, Delman KA, Spitler LE, Puzanov I, Agarwala SS, et al: Talimogene laherparepvec improves durable response rate in patients with advanced melanoma. J Clin Oncol 33: 2780-2788, 2015.

20. Guo ZS, Lu B, Guo Z, Giehl E, Feist M, Dai E, Liu W, Storkus WJ, He Y, Liu Z and Bartlett DL: Vaccinia virus-mediated cancer immunotherapy: Cancer vaccines and oncolytics. J Immunother Cancer 7: 6, 2019.

21. Kowalsky SJ, Liu Z,Feist M, Berkey SE, Ma C, Ravindranathan R, Dai E, Roy EJ, Guo ZS and Bartlett DL: Superagonist IL-15-armed oncolytic virus elicits potent antitumor immunity and therapy that are enhanced with PD-1 blockade. Mol Ther 26 2476-2486, 2018.

22. Wang N, Wang J, Zhang Z, Cao H, Yan W, Chu Y, Chard Dunmall LS and Wang Y: A novel vaccinia virus enhances anti-tumor efficacy and promotes a long-term anti-tumor response in a murine model of colorectal cancer. Mol Ther Oncolytics 20: 71-81, 2020.

23. Liu Z, Ravindranathan R, Kalinski P, Guo ZS and Bartlett DL: Rational combination of oncolytic vaccinia virus and PD-L1 blockade works synergistically to enhance therapeutic efficacy. Nat Commun 8: 14754, 2017.

24. Melero I, Gato M, Shekarian T, Aznar A, Valsesia-Wittmann S, Caux C, Etxeberrria I, Teijeira A and Marabelle A: Repurposing infectious disease vaccines for intratumoral immunotherapy. J Immunother Cancer 8: e000443, 2020.

25. Shekarian T, Sivado E, Jallas AC, Depil S, Kielbassa J, Janoueix-Lerosey I, Hutter G, Goutagny N, Bergeron C, Viari A, et al: Repurposing rotavirus vaccines for intratumoral immunotherapy can overcome resistance to immune checkpoint blockade. Sci Transl Med 11: eaat5025, 2019.

26. Shemesh CS, Hsu JC, Hosseini I, Shen BQ, Rotte A, Twomey P, Girish S and Wu B: Personalized cancer vaccines: Clinical landscape, challenges, and opportunities. Mol Ther 29: 555-570, 2021.

27. Liu R, Zhou C, Wang D, Ma W, Lin C, Wang Y, Liang X, Li J, Guo S, Wang Y, et al: Enhancement of DNA vaccine potency by sandwiching antigen-coding gene between secondary lymphoid tissue chemokine (SLC) and IgG Fc fragment genes. Cancer Biol Ther 5: 427-434, 2006.

28. Tondini E, Arakelian T, Oosterhuis K, Camps M, van Duikeren S, Han W, Arens R, Zondag G, van Bergen J and Ossendorp F: A poly-neoantigen DNA vaccine synergizes with PD-1 blockade to induce T cell-mediated tumor control. Oncoimmunology 8 : 1652539, 2019.

29. Xu G, Feng D, Yao Y, Li P, Sun H, Yang H, Li C, Jiang R, Sun B and Chen Y: Listeria-based hepatocellular carcinoma vaccine facilitates anti-PD-1 therapy by regulating macrophage polarization. Oncogene 39: 1429-1444, 2020.

30. Zhao H, Xu J, Li Y, Guan X, Han X, Xu Y,Zhou H, Peng R, Wang J and Liu Z: Nanoscale coordination polymer based nanovaccine for tumor immunotherapy. ACS Nano 13: 13127-13135, 2019.

31. Gibney GT, Kudchadkar RR, DeConti RC, Thebeau MS Czupryn MP, Tetteh L, Eysmans C, Richards A, Schell MJ, Fisher KJ, et al: Safety, correlative markers, and clinical results of adjuvant nivolumab in combination with vaccine in resected high-risk metastatic melanoma. Clin Cancer Res 21: 712-720, 2015.

32. Weber JS, Kudchadkar RR, Yu B, Gallenstein D, Horak CE, Inzunza HD, Zhao X, Martinez AJ, Wang W, Gibney G, et al: Safety, efficacy, and biomarkers of nivolumab with vaccine in ipilimumab-refractory or -naive melanoma. J Clin Oncol 31: 4311-4318, 2013

33. Ott PA, Hu Z, Keskin DB, Shukla SA, Sun J, Bozym DJ, Zhang W, Luoma A, Giobbie-Hurder A, Peter L, et al: An immunogenic personal neoantigen vaccine for patients with melanoma. Nature 547: 217-221, 2017.

34. Crosby EJ, Acharya CR, Haddad AF, Rabiola CA, Lei G, Wei JP Yang XY, Wang T, Liu CX, Wagner KU, et al: Stimulation of oncogene-specific tumor-infiltrating $\mathrm{T}$ cells through combined vaccine and $\alpha$ PD- 1 enable sustained antitumor responses against established HER2 breast cancer. Clin Cancer Res 26: 4670-4681, 2020.

35. Di Tacchio M, Macas J, Weissenberger J, Sommer K, Bähr O, Steinbach JP, Senft C, Seifert V, Glas M, Herrlinger U, et al: Tumor vessel normalization, immunostimulatory reprogramming, and improved survival in glioblastoma with combined inhibition of PD-1, angiopoietin-2, and VEGF. Cancer Immunol Res 7: 1910-1927, 2019.

36. Gao $\mathrm{F}$ and Yang C: Anti-VEGF/VEGFR2 monoclonal antibodies and their combinations with PD-1/PD-L1 inhibitors in clinic. Curr Cancer Drug Targets 20: 3-18, 2020.
37. Amin A, Plimack ER, Ernstoff MS, Lewis LD, Bauer TM, McDermott DF, Carducci M, Kollmannsberger C, Rini BI, Heng DYC, et al: Safety and efficacy of nivolumab in combination with sunitinib or pazopanib in advanced or metastatic renal cell carcinoma: The CheckMate 016 study. J Immunother Cancer 6: 109, 2018.

38. Zhao S, Ren S, Jiang T, Zhu B, Li X, Zhao C, Jia Y, Shi J, Zhang L, Liu X, et al: Low-dose apatinib optimizes tumor microenvironment and potentiates antitumor effect of PD-1/PD-L1 blockade in lung cancer. Cancer Immunol Res 7: 630-643, 2019.

39. Garcia J, Hurwitz HI, Sandler AB, Miles D, Coleman RL, Deurloo R and Chinot OL: Bevacizumab (Avastin ${ }^{\circledR}$ ) in cancer treatment: A review of 15 years of clinical experience and future outlook. Cancer Treat Rev 86: 102017, 2020.

40. Osada T, Chong G, Tansik R, Hong T, Spector N, Kumar R, Hurwitz HI, Dev I, Nixon AB, Lyerly HK, et al: The effect of anti-VEGF therapy on immature myeloid cell and dendritic cells in cancer patients. Cancer Immunol Immunother 57: 1115-1124, 2008.

41. McDermott DF, Huseni MA, Atkins MB, Motzer RJ, Rini BI, Escudier B, Fong L, Joseph RW, Pal SK, Reeves JA, et al: Clinical activity and molecular correlates of response to atezolizumab alone or in combination with bevacizumab versus sunitinib in renal cell carcinoma. Nat Med 24: 749-757, 2018.

42. Reck M, Mok TSK, Nishio M, Jotte RM, Cappuzzo F, Orlandi F, Stroyakovskiy D, Nogami N, Rodríguez-Abreu D, Moro-Sibilot D, et al: Atezolizumab plus bevacizumab and chemotherapy in non-small-cell lung cancer (IMpower150): Key subgroup analyses of patients with EGFR mutations or baseline liver metastases in a randomised, open-label phase 3 trial. Lancet Respir Med 7: 387-401, 2019.

43. Sigismund S, Avanzato D and Lanzetti L: Emerging functions of the EGFR in cancer. Mol Oncol 12: 3-20, 2018.

44. Liu Z, Han C, Dong C, Shen A, Hsu E, Ren Z, Lu C, Liu L, Zhang A, Timmerman C, et al: Hypofractionated EGFR tyrosine kinase inhibitor limits tumor relapse through triggering innate and adaptive immunity. Sci Immunol 4: eaav6473, 2019.

45. Wu SG and Shih JY: Management of acquired resistance to EGFR TKI-targeted therapy in advanced non-small cell lung cancer. Mol Cancer 17: 38, 2018.

46. Chen N, Fang W, Zhan J, Hong S, Tang Y, Kang S, Zhang Y, He X, Zhou T, Qin T, et al: Upregulation of PD-L1 by EGFR activation mediates the immune escape in EGFR-Driven NSCLC: Implication for optional immune targeted therapy for NSCLC patients with EGFR mutation. J Thorac Oncol 10: 910-923, 2015.

47. Camidge DR, Doebele RC and Kerr KM: Comparing and contrasting predictive biomarkers for immunotherapy and targeted therapy of NSCLC. Nat Rev Clin Oncol 16: 341-355, 2019.

48. Haratani K, Hayashi H, Tanaka T, Kaneda H, Togashi Y, Sakai K, Hayashi K, Tomida S, Chiba Y, Yonesaka K, et al: Tumor immune microenvironment and nivolumab efficacy in EGFR mutation-positive non-small-cell lung cancer based on T790M status after disease progression during EGFR-TKI treatment. Ann Oncol 28: 1532-1539, 2017

49. Garassino MC, Cho BC, Kim JH, Mazières J, Vansteenkiste J, Lena H, Corral Jaime J, Gray JE, Powderly J, Chouaid C, et al: Durvalumab as third-line or later treatment for advanced non-small-cell lung cancer (ATLANTIC): An open-label, single-arm, phase 2 study. Lancet Oncol 19: 521-536, 2018.

50. Yang JC, Gadgeel SM, Sequist LV, Wu CL, Papadimitrakopoulou VA, Su WC, Fiore J, Saraf S, Raftopoulos H and Patnaik A: Pembrolizumab in combination with erlotinib or gefitinib as first-line therapy for advanced NSCLC with sensitizing EGFR mutation. J Thorac Oncol 14: 553-559, 2019.

51. Zhai L, Bell A, Ladomersky E, Lauing KL, Bollu L, Sosman JA, Zhang B, Wu JD, Miller SD, Meeks JJ, et al: Immunosuppressive IDO in cancer: Mechanisms of action, animal models, and targeting strategies. Front Immunol 11: 1185, 2020.

52. Siu LL, Gelmon K, Chu Q, Pachynski R, Alese O, Basciano P, Walker J, Mitra P, Zhu L, Phillips P, et al: Abstract CT116: BMS-986205, an optimized indoleamine 2,3-dioxygenase 1 (IDO1) inhibitor, is well tolerated with potent pharmacodynamic (PD) activity, alone and in combination with nivolumab (nivo) in advanced cancers in a phase 1/2a trial. Cancer Res 77 (Suppl 13): CT116, 2017.

53. Zakharia Y, Rixe O, Ward JH, Drabick JJ, Shaheen MF, Milhem MM, Munn D, Kennedy EP, Vahanian NN, Link CJ, et al: Phase 2 trial of the IDO pathway inhibitor indoximod plus checkpoint inhibition for the treatment of patients with advanced melanoma. J Clin Oncol 36 (Suppl 15): S9512, 2018. 
54. Bahary N, Wang-Gillam A, Haraldsdottir S, Somer BG, Lee JS, O'Rourke MA, Nayak-Kapoor A, Beatty GL, Liu M, Delman D, et al: Phase 2 trial of the IDO pathway inhibitor indoximod plus gemcitabine/nab-paclitaxel for the treatment of patients with metastatic pancreas cancer. J Clin Oncol 36 (Suppl 15): S4015, 2018.

55. Jha GG, Gupta S, Tagawa ST, Koopmeiners JS, Vivek S, Dudek AZ, Cooley SA, Blazar BR and Miller JS: A phase II randomized, double-blind study of sipuleucel-T followed by IDO pathway inhibitor, indoximod, or placebo in the treatment of patients with metastatic castration resistant prostate cancer (mCRPC). J Clin Oncol 35 (Suppl 15): S3066, 2017.

56. Zakharia Y, Drabick JJ, Khleif S, McWilliams RR, Munn D, Link CJ, Vahanian NN, Kennedy E, Shaheen MF, Rixe O and Milhem MM: Updates on phase1b/2 trial of the indoleamine 2,3-dioxygenase pathway (IDO) inhibitor indoximod plus checkpoint inhibitors for the treatment of unresectable stage 3 or 4 melanoma. J Clin Oncol 34 (Suppl 15): S3075, 2016.

57. Hamid O,BauerTM,Spira AI,Smith DC, Olszanski AJ, Tarhini AA, Lara P, Gajewski T, Wasser JS, Patel SP, et al: Safety of epacadostat $100 \mathrm{mg}$ bid plus pembrolizumab $200 \mathrm{mg}$ Q3W in advanced solid tumors: Phase 2 data from ECHO-202/KEYNOTE-037. J Clin Oncol 35 (Suppl 15): S3012, 2017.

58. Andrews LP, Marciscano AE, Drake CG and Vignali DA: LAG3 (CD223) as a cancer immunotherapy target. Immunol Rev 276 80-96, 2017.

59. Huang RY, Eppolito C, Lele S, Shrikant P, Matsuzaki J and Odunsi K: LAG3 and PD1 co-inhibitory molecules collaborate to limit CD8+ T cell signaling and dampen antitumor immunity in a murine ovarian cancer model. Oncotarget 6: 27359-27377, 2015.

60. Goding SR, Wilson KA, Xie Y, Harris KM, Baxi A, Akpinarli A, Fulton A, Tamada K, Strome SE and Antony PA: Restoring immune function of tumor-specific $\mathrm{CD} 4+\mathrm{T}$ cells during recurrence of melanoma. J Immunol 190: 4899-4909, 2013.

61. Dahlén E, Veitonmäki N and Norlén P: Bispecific antibodies in cancer immunotherapy. Ther Adv Vaccines Immunother 6: 3-17, 2018.

62. Ascierto PA, Bhatia S, Bono P, Bono P, Sanborn RE, Lipson EJ, Callahan MK, Gajewski T, Gomez-Roca CA, Hodi FS, et al: Initial efficacy of anti-lymphocyte activation gene-3 (anti-LAG-3; BMS-986016) in combination with nivolumab (nivo) in PTS with melanoma (MEL) previously treated with anti-PD-1/PD-L1 therapy. J Clini Oncol 35 (Suppl 15): S9520, 2017.

63. Puhr HC and Ilhan-Mutlu A: New emerging targets in cancer immunotherapy: The role of LAG3. ESMO Open 4: e000482, 2019.

64. Yasinska IM, Sakhnevych SS, Pavlova L, Teo Hansen Selnø A, Teuscher Abeleira AM, Benlaouer O, Gonçalves Silva I, Mosimann M, Varani L, Bardelli M, et al: The Tim-3-galectin-9 pathway and its regulatory mechanisms in human breast cancer. Front Immunol 10: 1594, 2019.

65. Li H, Wu K, Tao K, Chen L, Zheng Q, Lu X, Liu J, Shi L, Liu C, Wang $\mathrm{G}$ and Zou W: Tim-3/galectin-9 signaling pathway mediates T-cell dysfunction and predicts poor prognosis in patients with hepatitis B virus-associated hepatocellular carcinoma. Hepatology 56: 1342-1351, 2012.

66. Kurtulus S, Madi A,Escobar G,KlapholzM,Nyman J,ChristianE, Pawlak M, Dionne D, Xia J, Rozenblatt-Rosen O, et al: Checkpoint blockade immunotherapy induces dynamic changes in PD-1 ${ }^{-} \mathrm{CD}^{+}$tumor-infiltrating T cells. Immunity 50: 181-194. e6, 2019.

67. Sakuishi K, Apetoh L, Sullivan JM, Blazar BR, Kuchroo VK and Anderson AC: Targeting Tim-3 and PD-1 pathways to reverse $\mathrm{T}$ cell exhaustion and restore anti-tumor immunity. J Exp Med 207: 2187-2194, 2010.

68. Sun F, Guo ZS, Gregory AD, Shapiro SD, Xiao G and Qu Z: Dual but not single PD-1 or TIM-3 blockade enhances oncolytic virotherapy in refractory lung cancer. J Immunother Cance 8: e000294, 2020 .

69. Huang TY, Huang GL, Zhang CY, Zhuang BW, Liu BX, Su LY, Ye JY, Xu M, Kuang M and Xie XY: Supramolecular photothermal nanomedicine mediated distant tumor inhibition via PD-1 and TIM-3 blockage. Front Chem 8: 1, 2020.

70. Gestermann N, Saugy D, Martignier C, Tillé L, Fuertes Marraco SA, Zettl M, Tirapu I, Speiser DE and Verdeil G: LAG-3 and PD-1+LAG-3 inhibition promote anti-tumor immune responses in human autologous melanoma/T cell co-cultures. Oncoimmunology 9: 1736792, 2020.
71. Friedlaender A, Addeo A and Banna G: New emerging targets in cancer immunotherapy: The role of TIM3. ESMO Open 4 (Suppl 3): e000497, 2019.

72. Davar D, Boasberg PD, Eroglu Z, Falchook G, Gainor J, Hamilton E, Hecht R, Luke J, Pishvaian M, Ribas A, et al: Abstract O21: A phase 1 study of TSR-022, an anti-TIM-3 monoclonal antibody, in combination with TSR-042 (anti-PD-1) in patients with colorectal cancer and post-PD-1 NSCLC and melanoma. J Immuno Therapy Cancer 6 (Suppl 1): S155, 2018.

73. Wu L, Mao L, Liu JF, Chen L, Yu GT, Yang LL, Wu H, Bu LL, Kulkarni AB, Zhang WF and Sun ZJ: Blockade of TIGIT/CD155 signaling reverses T-cell exhaustion and enhances antitumor capability in head and neck squamous cell carcinoma. Cancer Immunol Res 7: 1700-1713, 2019.

74. Chauvin JM, Pagliano O, Fourcade J, Sun Z, Wang H, Sander C, Kirkwood JM, Chen TH, Maurer M, Korman AJ and Zarour HM TIGIT and PD-1 impair tumor antigen-specific CD8 ${ }^{+} \mathrm{T}$ cells in melanoma patients. J Clin Invest 125: 2046-2058, 2015.

75. Grapin M, Richard C, Limagne E, Boidot R, Morgand V, Bertaut A, Derangere V, Laurent PA, Thibaudin M, Fumet JD, et al: Optimized fractionated radiotherapy with anti-PD-L1 and anti-TIGIT: A promising new combination. J Immunother Cancer 7: 160, 2019.

76. Johnston RJ, Comps-Agrar L, Hackney J, Yu X, Huseni M, Yang Y, Park S, Javinal V, Chiu H, Irving B, et al: The immunoreceptor TIGIT regulates antitumor and antiviral CD8(+) T cell effector function. Cancer Cell 26: 923-937, 2014.

77. Kurtulus S, Sakuishi K, Ngiow SF, Joller N, Tan DJ, Teng MW, Smyth MJ, Kuchroo VK and Anderson AC: TIGIT predominantly regulates the immune response via regulatory $\mathrm{T}$ cells J Clin Invest 125: 4053-4062, 2015.

78. Finetti $\mathrm{F}$ and Baldari CT: The immunological synapse as a pharmacological target. Pharmacol Res 134: 118-133,2018.

79. Chester C, Sanmamed MF, Wang J and Melero I: Immunotherapy targeting 4-1BB: Mechanistic rationale, clinical results, and future strategies. Blood 131: 49-57, 2018.

80. Morales-Kastresana A, Sanmamed MF, Rodriguez I, Palazon A, Martinez-Forero I, Labiano S, Hervas-Stubbs S, Sangro B, Ochoa C, Rouzaut A, et al: Combined immunostimulatory monoclonal antibodies extend survival in an aggressive transgenic hepatocellular carcinoma mouse model. Clin Cancer Res 19: 6151-6162, 2013.

81. Fisher TS, Kamperschroer C, Oliphant T, Love VA, Lira PD, Doyonnas R, Bergqvist S, Baxi SM, Rohner A, Shen AC, et al: Targeting of 4-1BB by monoclonal antibody PF-05082566 enhances T-cell function and promotes anti-tumor activity. Cancer Immunol Immunother 61: 1721-1733, 2012.

82. Segal NH, He AR, Doi T, Levy R, Bhatia S, Pishvaian MJ, Cesari R, Chen Y, Davis CB, Huang B, et al: Phase I study of single-agent utomilumab (PF-05082566), a 4-1BB/CD137 agonist, in patients with advanced cancer. Clin Cancer Res 24: 1816-1823, 2018

83. Tolcher AW, Sznol M, Hu-Lieskovan S, Papadopoulos KP, Patnaik A, Rasco DW, Di Gravio D, Huang B, Gambhire D, Chen Y, et al: Phase Ib study of utomilumab (PF-05082566), a 4-1BB/CD137 agonist, in combination with pembrolizumab (MK-3475) in patients with advanced solid tumors. Clin Cancer Res 23: 5349-5357, 2017.

84. Masserelli E, Segal NH and Ribrag V: Clinical safety and efficacy assessment of the CD137 agonist urelumab alone and in combination with nivolumab in patients with hematologic and solid tumor malignancies. J Immunother Cancer 4: O7, 2016.

85. Callahan MK, Postow MA and Wolchok JD: Immunomodulatory therapy for melanoma: Ipilimumab and beyond. Clin Dermatol 31: 191-199, 2013.

86. Boutros C, Tarhini A, Routier E, Lambotte O, Ladurie FL, Carbonnel F, Izzeddine H, Marabelle A, Champiat S, Berdelou A, et al: Safety profiles of anti-CTLA-4 and anti-PD-1 antibodies alone and in combination. Nat Rev Clin Oncol 13: 473-486, 2016.

87. Postow MA, Chesney J, Pavlick AC, Robert C, Grossmann K, McDermott D, Linette GP, Meyer N, Giguere JK, Agarwala SS, et al: Nivolumab and ipilimumab versus ipilimumab in untreated melanoma. N Engl J Med 372: 2006-2017, 2015.

88. Larkin J, Chiarion-Sileni V, Gonzalez R, Grob JJ, Cowey CL, Lao CD, Schadendorf D, Dummer R, Smylie M, Rutkowski P, et al: Combined nivolumab and ipilimumab or monotherapy in untreated melanoma. N Engl J Med 373: 23-34, 2015. 
89. Omuro A, Vlahovic G, Lim M, Sahebjam S, Baehring J, Cloughesy T, Voloschin A, Ramkissoon SH, Ligon KL, Latek R, et al: Nivolumab with or without ipilimumab in patients with recurrent glioblastoma: Results from exploratory phase I cohorts of CheckMate 143. Neuro Oncol 20: 674-686, 2018.

90. Kitao H, Iimori M, Kataoka Y, Wakasa T, Tokunaga E, Saeki H, Oki E and Maehara Y: DNA replication stress and cancer chemotherapy. Cancer Sci 109: 264-271, 2018.

91. Gotwals P, Cameron S, Cipolletta D, Cremasco V, Crystal A, Hewes B, Mueller B, Quaratino S, Sabatos-Peyton C, Petruzzelli L, et al: Prospects for combining targeted and conventional cancer therapy with immunotherapy. Nat Rev Cancer 17: 286-301, 2017.

92. Langer CJ, Gadgeel SM, Borghaei H, Papadimitrakopoulou VA, Patnaik A, Powell SF, Gentzler RD, Martins RG, Stevenson JP, Jalal SI, et al: Carboplatin and pemetrexed with or without pembrolizumab for advanced, non-squamous non-small-cell lung cancer: A randomised, phase 2 cohort of the open-label KEYNOTE-021 study. Lancet Oncol 17: 1497-1508, 2016.

93. Gandhi L, Rodríguez-Abreu D, Gadgeel S, Esteban E, Felip E, De Angelis F, Domine M, Clingan P, Hochmair MJ, Powell SF, et al: Pembrolizumab plus chemotherapy in metastatic non-small-cell lung cancer. N Engl J Med 378: 2078-2092, 2018.

94.Paz-Ares L, Luft A, Vicente D, Tafreshi A, Gümüş M Mazières J, Hermes B, Çay Senler F, Csőszi T, Fülöp A, et al: Pembrolizumab plus chemotherapy for squamous non-small-cell lung cancer. N Engl J Med 379: 2040-2051, 2018.

95. Deng L, Liang $H$, Burnette B, Beckett $M$, Darga $T$, Weichselbaum RR and Fu YX: Irradiation and anti-PD-L1 treatment synergistically promote antitumor immunity in mice. J Clin Invest 124: 687-695, 2014.

96. Lhuillier C, Rudqvist NP, Elemento O, Formenti SC and Demaria S: Radiation therapy and anti-tumor immunity: Exposing immunogenic mutations to the immune system. Genome Med 11: 40, 2019.

97. Chen D, Barsoumian HB, Yang L, Younes AI, Verma V, Hu Y, Menon H, Wasley M, Masropour F, Mosaffa S, et al: SHP-2 and PD-L1 inhibition combined with radiotherapy enhances systemic antitumor effects in an anti-PD-1-resistant model of non-small cell lung cancer. Cancer Immunol Res 8: 883-894, 2020.

98. Antonia SJ, Villegas A, Daniel D, Vicente D, Murakami S, Hui R, Yokoi T, Chiappori A, Lee KH, de Wit M, et al: Durvalumab after chemoradiotherapy in stage III non-small-cell lung cancer. N Engl J Med 377: 1919-1929, 2017.

99. Sharabi AB, Nirschl CJ, Kochel CM, Nirschl TR, Francica BJ, Velarde E, Deweese TL and Drake CG: Stereotactic radiation therapy augments antigen-specific PD-1-mediated antitumor immune responses via cross-presentation of tumor antigen. Cancer Immunol Res 3: 345-355, 2015

100. Dudzinski SO, Cameron BD, Wang J, Rathmell JC, Giorgio TD and Kirschner AN: Combination immunotherapy and radiotherapy causes an abscopal treatment response in a mouse model of castration resistant prostate cancer. J Immunother Cancer 7 : 218, 2019.

101. Dovedi SJ, Adlard AL, Lipowska-Bhalla G, McKenna C, Jones S, Cheadle EJ, Stratford IJ, Poon E, Morrow M, Stewart R, et al: Acquired resistance to fractionated radiotherapy can be overcome by concurrent PD-L1 blockade. Cancer Res 74: 5458-5468, 2014

102. Ahmed KA, Stallworth DG, Kim Y, Johnstone PA, Harrison LB, Caudell JJ, Yu HH, Etame AB, Weber JS and Gibney GT: Clinical outcomes of melanoma brain metastases treated with stereotactic radiation and anti-PD-1 therapy. Ann Oncol 27: 434-441, 2016.

103. Chowdhury PS, Chamoto K and Honjo T: Combination therapy strategies for improving PD-1 blockade efficacy: A new era in cancer immunotherapy. J Intern Med 283: 110-120, 2018

104. Formenti SC and Demaria S: Radiation therapy to convert the tumor into an in situ vaccine. Int J Radiat Oncol Biol Phys 84 879-880, 2012.

105. Liang H, Deng L, Hou Y, Meng X, Huang X, Rao E, Zheng W, Mauceri H, Mack M, Xu M, et al: Host STING-dependent MDSC mobilization drives extrinsic radiation resistance. Nat Commun 8: 1736, 2017.

106. Seyedin SN, Hasibuzzaman MM, Pham V, Petronek MS, Callaghan C, Kalen AL, Mapuskar KA, Mott SL, Spitz DR, Allen BG and Caster JM: Combination therapy with radiation and PARP inhibition enhances responsiveness to anti-PD-1 therapy in colorectal tumor models. Int J Radiat Oncol Biol Phys 108: 81-92, 2020.
107. Theelen WSME, Peulen HMU, Lalezari F, van der Noort V, de Vries JF, Aerts JGJV, Dumoulin DW, Bahce I, Niemeijer AN de Langen AJ, et al: Effect of pembrolizumab after stereotactic body radiotherapy vs pembrolizumab alone on tumor response in patients with advanced non-small cell lung cancer: Results of the PEMBRO-RT phase 2 randomized clinical trial. JAMA Oncol 5: 1276-1282, 2019.

108. Arina A, Gutiontov SI and Weichselbaum RR: Radiotherapy and immunotherapy for cancer: From 'systemic; to 'multisite' Clin Cancer Res 26: 2777-2782, 2020.

109. Vanpouille-Box C, Alard A, Aryankalayil MJ, Sarfraz Y, Diamond JM, Schneider RJ, Inghirami G, Coleman CN, Formenti SC and Demaria S: DNA exonuclease Trex1 regulates radiotherapy-induced tumour immunogenicity. Nat Commun 8: 15618,2017

110. Lugade AA, Moran JP, Gerber SA, Rose RC, Frelinger JG and Lord EM: Local radiation therapy of B16 melanoma tumors increases the generation of tumor antigen-specific effector cells that traffic to the tumor. J Immunol 174: 7516-7523, 2005.

111. Kordbacheh T, Honeychurch J, Blackhall F, Faivre-Finn $\mathrm{C}$ and Illidge T: Radiotherapy and anti-PD-1/PD-L1 combinations in lung cancer: Building better translational research platforms. Ann Oncol 29: 301-310, 2018.

112. Sivan A, Corrales L, Hubert N, Williams JB, Aquino-Michaels K, Earley ZM, Benyamin FW, Lei YM, Jabri B, Alegre ML, et al: Commensal bifidobacterium promotes antitumor immunity and facilitates anti-PD-L1 efficacy. Science 350: 1084-1089, 2015.

113. Song P, Yang D, Wang H, Cui X, Si X, Zhang X and Zhang L: Relationship between intestinal flora structure and metabolite analysis and immunotherapy efficacy in Chinese NSCLC patients. Thorac Cancer 11: 1621-1632, 2020.

114. Tanoue T, Morita S, Plichta DR, Skelly AN, Suda W, Sugiura Y, Narushima S, Vlamakis H, Motoo I, Sugita K, et al: A defined commensal consortium elicits CD8 T cells and anti-cancer immunity. Nature 565: 600-605, 2019.

115. Routy B, Le Chatelier E, Derosa L, Duong CPM, Alou MT, Daillère R, Fluckiger A, Messaoudene M, Rauber C, Roberti MP, et al: Gut microbiome influences efficacy of PD-1-based immunotherapy against epithelial tumors. Science 359: 91-97, 2018.

116. Baruch EN, Youngster I, Ben-Betzalel G, Ortenberg R, Lahat A Katz L, Adler K, Dick-Necula D, Raskin S, Bloch N, et al: Fecal microbiota transplant promotes response in immunotherapy-refractory melanoma patients. Science 371: 602-609, 2021.

117. Kikuchi T, Mimura K, Ashizawa M, Okayama H, Endo E, Saito K, Sakamoto W, Fujita S, Endo H, Saito M, et al: Characterization of tumor-infiltrating immune cells in relation to microbiota in colorectal cancers. Cancer Immunol Immunother 69: 23-32, 2020.

118. Dubin K, Callahan MK, Ren B, Khanin R, Viale A, Ling L, No D, Gobourne A, Littmann E, Huttenhower C, et al: Intestinal microbiome analyses identify melanoma patients at risk for checkpoint-blockade-induced colitis. Nat Commun 7: 10391, 2016.

119. Xu X, Lv J, Guo F, Li J, Jia Y, Jiang D, Wang N, Zhang C, Kong L, Liu Y, et al: Gut microbiome influences the efficacy of PD-1 antibody immunotherapy on MSS-type colorectal cancer via metabolic pathway. Front Microbiol 11: 814, 2020.

120. Gopalakrishnan V, Spencer CN, Nezi L, Reuben A, Andrews MC, Karpinets TV, Prieto PA, Vicente D, Hoffman K, Wei SC, et al: Gut microbiome modulates response to anti-PD-1 immunotherapy in melanoma patients. Science 359: 97-103, 2018.

121. Frankel AE, Coughlin LA, Kim J, Froehlich TW, Xie Y, Frenkel EP and Koh AY: Metagenomic shotgun sequencing and unbiased metabolomic profiling identify specific human gut microbiota and metabolites associated with immune checkpoint therapy efficacy in melanoma patients. Neoplasia 19: 848-855, 2017.

122. Matson V, Fessler J, Bao R, Chongsuwat T, Zha Y, Alegre ML, Luke JJ and Gajewski TF: The commensal microbiome is associated with anti-PD-1 efficacy in metastatic melanoma patients. Science 359: 104-108, 2018.

123. Sethi G, Shanmugam MK, Warrier S, Merarchi M, Arfuso F, Kumar AP and Bishayee A: Pro-apoptotic and anti-cancer properties of diosgenin: A comprehensive and critical review. Nutrients 10: 645, 2018.

124. Dong M, Meng Z, Kuerban K, Qi F, Liu J, Wei Y, Wang Q, Jiang S, Feng $M$ and Ye L: Diosgenin promotes antitumor immunity and PD-1 antibody efficacy against melanoma by regulating intestinal microbiota. Cell Death Dis 9: 1039, 2018. 
125. Hao H, Zhang Q, Zhu H, Wen Y, Qiu D, Xiong J, Fu X, Wu Y, Meng $\mathrm{K}$ and $\mathrm{Li}$ J: Icaritin promotes tumor T-cell infiltration and induces antitumor immunity in mice. Eur J Immunol 49: 2235-2244, 2019.

126. Li W, Kim TI, Kim JH and Chung HS: Immune checkpoint PD-1/PD-L1 CTLA-4/CD80 are blocked by Rhus verniciflua stokes and its active compounds. Molecules 24: 4062, 2019.

127. Wang G, Wang L, Zhou J and Xu X: The possible Role of PD-1 protein in Ganoderma lucidum-mediated immunomodulation and cancer treatment. Integr Cancer Ther 18: 1534735419880275 , 2019.

128. Su J, Li D, Chen Q, Li M, Su L, Luo T, Liang D, Lai G, Shuai O, Jiao C, et al: Anti-breast cancer enhancement of a polysaccharide from spore of Ganoderma lucidum with paclitaxel: Suppression on tumor metabolism with gut microbiota reshaping. Front Microbiol 9: 3099, 2018

129. Herbst RS, Soria JC, Kowanetz M, Fine GD, Hamid O, Gordon MS, Sosman JA, McDermott DF, Powderly JD, Gettinger SN, et al: Predictive correlates of response to the anti-PD-L1 antibody MPDL3280A in cancer patients. Nature 515: 563-567, 2014.

130. Taube JM, Klein A, Brahmer JR, Xu H, Pan X, Kim JH, Chen L, Pardoll DM, Topalian SL and Anders RA: Association of PD-1, PD-1 ligands, and other features of the tumor immune microenvironment with response to anti-PD-1 therapy. Clin Cancer Res 20: 5064-5074, 2014.

131. Taube JM, Anders RA, Young GD, Xu H, Sharma R McMiller TL, Chen S, Klein AP, Pardoll DM, Topalian SL and Chen L: Colocalization of inflammatory response with B7-h1 expression in human melanocytic lesions supports an adaptive resistance mechanism of immune escape. Sci Transl Med 4: 127ra37, 2012

132. Madore J, Vilain RE, Menzies AM, Kakavand H, Wilmott JS, Hyman J, Yearley JH, Kefford RF, Thompson JF, Long GV, et al: PD-L1 expression in melanoma shows marked heterogeneity within and between patients: Implications for anti-PD-1/PD-L1 clinical trials. Pigment Cell Melanoma Res 28: 245-253, 2015.

133. Adams DL, Adams DK, He J, Kalhor N, Zhang M, Xu T, Gao H, Reuben JM, Qiao Y, Komaki R, et al: Sequential tracking of PD-L1 expression and RAD50 induction in circulating tumor and stromal cells of lung cancer patients undergoing radiotherapy. Clin Cancer Res 23: 5948-5958, 2017.

134. Hansen AR and Siu LL: PD-L1 testing in cancer: Challenges in companion diagnostic development. JAMA Oncol 2: 15-16, 2016.

135. Sacher AG and Gandhi L: Biomarkers for the clinical use of PD-1/PD-L1 inhibitors in non-small-cell lung cancer: A review. JAMA Oncol 2: 1217-1222, 2016.

136. Mahoney KM, Sun H, Liao X, Hua P, Callea M, Greenfield EA, Hodi FS, Sharpe AH, Signoretti S, Rodig SJ and Freeman GJ: PD-L1 antibodies to its cytoplasmic domain most clearly delineate cell membranes in immunohistochemical staining of tumor cells. Cancer Immunol Res 3: 1308-1315, 2015.

137. Ahmadzadeh M, Johnson LA, Heemskerk B, Wunderlich JR, Dudley ME, White DE and Rosenberg SA: Tumor antigen-specific CD8 T cells infiltrating the tumor express high levels of PD-1 and are functionally impaired. Blood 114: 1537-1544, 2009.

138. Honda Y, Otsuka A, Ono S, Yamamoto Y, Seidel JA, Morita S, Hirata M, Kataoka TR, Takenouchi T, Fujii K, et al: Infiltration of PD-1-positive cells in combination with tumor site PD-L1 expression is a positive prognostic factor in cutaneous angiosarcoma. Oncoimmunology 6: e1253657, 2016.

139. Zhang Y, Kang S, Shen J, He J, Jiang L, Wang W, Guo Z, Peng G, Chen G, He J and Liang W: Prognostic significance of programmed cell death 1 (PD-1) or PD-1 ligand 1 (PD-L1) Expression in epithelial-originated cancer: A meta-analysis. Medicine (Baltimore) 94: e515, 2015.

140. Stanton SE and Disis ML: Clinical significance of tumor-infiltrating lymphocytes in breast cancer. J Immunother Cancer 4: 59, 2016.

141. Kawakami F, Sircar K, Rodriguez-Canales J, Fellman BM, Urbauer DL, Tamboli P, Tannir NM, Jonasch E, Wistuba II, Wood CG and Karam JA: Programmed cell death ligand 1 and tumor-infiltrating lymphocyte status in patients with renal cell carcinoma and sarcomatoid dedifferentiation. Cancer 123 : 4823-4831, 2017.

142. Zhang Y and Chen L: Classification of advanced human cancers based on tumor immunity in the microenvironment (TIME) for cancer immunotherapy. JAMA Oncol 2: 1403-1404, 2016.

143. De Ruysscher D: Combination of radiotherapy and immune treatment: First clinical data. Cancer Radiother 22: 564-566, 2018.
144. Vansteenkiste J, Wauters E, Reymen B, Ackermann CJ, Peters S and De Ruysscher D: Current status of immune checkpoint inhibition in early-stage NSCLC. Ann Oncol 30: 1244-1253, 2019.

145. Sahin IH, Akce M, Alese O, Shaib W, Lesinski GB, El-Rayes B and $\mathrm{Wu} C$ : Immune checkpoint inhibitors for the treatment of MSI-H/MMR-D colorectal cancer and a perspective on resistance mechanisms. Br J Cancer 121: 809-818, 2019.

146. Narayanan S, Kawaguchi T, Peng X, Qi Q, Liu S, Yan L and Takabe K: Tumor infiltrating lymphocytes and macrophages improve survival in microsatellite unstable colorectal cancer. Sci Rep 9: 13455, 2019.

147. Diaz LA Jr and Le DT: PD-1 blockade in tumors with mismatch-repair deficiency. N Engl J Med 373: 1979, 2015.

148. Wang $\mathrm{X}$ and Li M: Correlate tumor mutation burden with immune signatures in human cancers. BMC Immunol 20: 4, 2019.

149. Rizvi H, Sanchez-Vega F, La K, Chatila W, Jonsson P, Halpenny D, Plodkowski A, Long N, Sauter JL, Rekhtman N, et al: Molecular determinants of response to anti-programmed cell death (PD)-1 and anti-programmed death-ligand 1 (PD-L1) blockade in patients with non-small-cell lung cancer profiled with targeted next-generation sequencing. J Clin Oncol 36: 633-641, 2018.

150. Chen D, Barsoumian HB, Fischer G, Yang L, Verma V, Younes AI, $\mathrm{Hu}$ Y, Masropour F, Klein K, Vellano C, et al: Combination treatment with radiotherapy and a novel oxidative phosphorylation inhibitor overcomes PD-1 resistance and enhances antitumor immunity. J Immunother Cancer 8: e000289, 2020.

151. Wolchok JD, Chiarion-Sileni V, Gonzalez R, Rutkowski P, Grob JJ, Cowey CL, Lao CD, Wagstaff J, Schadendorf D, Ferrucci PF, et al: Overall survival with combined nivolumab and ipilimumab in advanced melanoma. N Engl J Med 377: 1345-1356, 2017.

152. Robert C, Schachter J, Long GV, Arance A, Grob JJ, Mortier L, Daud A, Carlino MS, McNeil C, Lotem M, et al: Pembrolizumab versus ipilimumab in advanced melanoma. N Engl J Med 372: 2521-2532, 2015.

153. Abdel-Rahman O and Fouad M: A network meta-analysis of the risk of immune-related renal toxicity in cancer patients treated with immune checkpoint inhibitors. Immunotherapy 8: 665-674, 2016.

154. Freeman-Keller M, Kim Y, Cronin H, Richards A, Gibney G and Weber JS: Nivolumab in resected and unresectable metastatic melanoma: Characteristics of immune-related adverse events and association with outcomes. Clin Cancer Res 22: 886-894, 2016.

155. Sun J, Lu Q, Sanmanmed MF and Wang J: Siglec-15 as an emerging target for next-generation cancer immunotherapy. Clin Cancer Res 27: 680-688, 2021

156. Jiang L, Gong X, Liao W, Lv N and Yan R: Molecular targeted treatment and drug delivery system for gastric cancer. J Cancer Res Clin Oncol: Feb 7, 2021 (Epub ahead of print)

157. Schoenfeld AJ, Arbour KC, Rizvi H, Iqbal AN, Gadgeel SM, Girshman J, Kris MG, Riely GJ, Yu HA and Hellmann MD Severe immune-related adverse events are common with sequential PD-(L)1 blockade and osimertinib. Ann Oncol 30: 839-844, 2019.

158. Uchida T, Kaira K, Yamaguchi O, Mouri A, Shiono A, Miura Y, Hashimoto K, Nishihara F, Murayama Y, Kobayashi K and Kagamu H: Different incidence of interstitial lung disease according to different kinds of EGFR-tyrosine kinase inhibitors administered immediately before and/or after anti-PD-1 antibodies in lung cancer. Thorac Cancer 10: 975-979, 2019.

159. Burtness B,HarringtonKJ,GreilR,SoulieresD, TaharaM,deCastro Junior G, Psyrri A, Rotllan NB, Neupane PC, Bratland A, et al: LBA8_PRKEYNOTE-048: phase III study of first-line pembrolizumab $(\mathrm{P})$ for recurrent/metastatic head and neck squamous cell carcinoma (R/M HNSCC). Ann Oncol 29 (Suppl 8): viii729, 2018.

160. Sasaki A, Nakamura Y, Togashi Y, Kuno H, Hojo H, Kageyama S Nakamura N, Takashima K, Kadota T, Yoda Y, et al: Enhanced tumor response to radiotherapy after PD-1 blockade in metastatic gastric cancer. Gastric Cancer 23: 893-903, 2020.

161. Samuel E, Lie G, Balasubramanian A, Hiong A, So Y, Voskoboynik M, Moore M, Shackleton M, Haydon A,John T, et al: Impact of radiotherapy on the efficacy and toxicity of anti-PD-1 inhibitors in metastatic NSCLC. Clin Lung Cancer S1525-7304 30183-30192, 2020 (Epub ahead of print).

This work is licensed under a Creative Commons Attribution-NonCommercial-NoDerivatives 4.0 International (CC BY-NC-ND 4.0) License. 